\title{
Fine-scale temporal and spatial patterns of larval supply to a fringing reef in Western Australia
}

\author{
J. L. McIlwain ${ }^{1,2, *}$ \\ ${ }^{2}$ Australian Institute of Marine Science, PO Box 83, Fremantle 6959, Western Australia, Australia \\ ${ }^{2}$ Present address: Department of Marine Science \& Fisheries, Sultan Qaboos University, PO Box 34, Al-Khod 123, \\ Sultanate of Oman
}

\begin{abstract}
The abundance and diversity of larval fish entering the lagoon of Ningaloo Reef, Western Australia, was monitored every day over a 4 to 5 mo period for each of 2 consecutive summers. This was done by deploying reef crest nets in the surf zone to capture the larvae making the transition from the pelagic environment to the lagoon. In the first summer, 2 nets $500 \mathrm{~m}$ apart were deployed for 94 nights. In the second summer, these same nets were redeployed in the same location along with an additional pair located $5 \mathrm{~km}$ to the south. These 4 nets were deployed for 101 nights. A total of 89598 presettlement fish from 65 families/groups was caught over both years with most fish coming from the Gobiidae, Blennidae, Labridae, Apogonidae and Lutjanidae families. Fewer larvae were caught in the second summer compared to the first. For both summers, the majority of the catch arrived during November and December, with abundance declining gradually as the season progressed. To examine periodicity in arrival, time series analysis was performed on 25 of the most abundant families/taxa. Larvae from different families and with entirely different morphologies arrived on a semi-lunar basis, such as the leptocephali, labrids and scorpaenids, whilst others arrived during cycles of less than $30 \mathrm{~d}$ (soles), approximately $28 \mathrm{~d}$ (leptocephali), greater than $30 \mathrm{~d}$ (Omobranchini blennies) and stochastically (some gobies, apogonids and labrids). Cross-correlation techniques were used to compare differences in abundance at 2 spatial scales: $5 \mathrm{~km}$ and $500 \mathrm{~m}$. I found multi-specific patches of larvae at least $5 \mathrm{~km}$ wide crossing the reef crest into the lagoon habitat. The timing of these patches was often chaotic and rarely lasted longer than $24 \mathrm{~h}$. I found that reef crest nets were an appropriate sampling tool for Ningaloo Reef, catching a rich assemblage of presettlement fish rarely seen on Australian coral reefs. I compare larval replenishment patterns at Ningaloo with other studies from the Caribbean, Central Pacific, Bahamas and eastern Australia, and discuss the importance of continuing to monitor larval assemblages at new locations preferably using modified, fixed plankton nets.
\end{abstract}

KEY WORDS: Larval supply $\cdot$ Coral reef fish $\cdot$ Recruitment $\cdot$ Ningaloo $\cdot$ Settlement $\cdot$ Lunar periodicity Crest nets Resale or republication not permitted without written consent of the publisher

\section{INTRODUCTION}

In the past $15 \mathrm{yr}$, the drive to understand small-scale temporal and spatial patterns in the recruitment process of coral reef fish has seen a rapid increase in the development of novel techniques to collect the data. These techniques have largely replaced visual census methods as the primary tools for measuring larval arrival and settlement of coral reef fish populations. As well as an improvement in the techniques used to catch late-stage larvae, there has been a concomitant development in the application of advanced statistical techniques like time-series analysis, which has increased the power to detect relationships between physical and biological parameters as well as to detect periodicity in larval supply (Milicich 1992, 1994, Thorrold et al. 1994c). In doing so, both of these developments have helped narrow the gap in our understand- 
ing of the processes that drive larval replenishment patterns.

At several locations in the Caribbean, Bahamas, and the Central and Western Pacific either light-traps or nets have been used, with considerable success, to catch larvae as they leave the plankton to settle to the reef. The underlying pattern of replenishment at all of these localities was enormous temporal variability at a number of scales. For example, all of the studies that investigated larval abundance over 2 or more consecutive years observed significant inter-annual variability, a pattern that was persistent across all taxonomic groups (Milicich \& Doherty 1994, Thorrold et al. 1994a, Sponaugle \& Cowen 1996, Kingsford \& Finn 1997). Within year-class seasonality of replenishment was also extremely variable and dependent on geographic location (Doherty 1991). In the Western Pacific, supply was restricted to a few lunar cycles during the summer months (Meekan 1992, Milicich 1992); whereas in the Bahamas and Caribbean, it was found to be a year long event (Thorrold et al. 1994a,b).

The patterns that have emerged from several recent studies of larval supply suggest both the timing and magnitude of abundance can be similar for different taxonomic groups. Sponaugle \& Cowen (1996a) found the highest diversity and abundance across all families occurred during the third quarter moon, 7 to $9 \mathrm{~d}$ after the full moon. Species from different families, such as Stegastes partitus and Acanthurus bahianus, exhibited identical temporal patterns in abundance (Sponaugle \& Cowen 1996b). Similarly, in the Bahamas, larval bothids and leptocephali arrived around the new moon, a pattern that was consistent between years and not always correlated with wind and currents (Thorrold et al. 1994a). These studies and others (e.g. Milicich \& Doherty 1994) suggest there is a growing body of evidence which advocates that replenishment patterns are determined largely by larval behaviour and are decoupled from adult spawning patterns (Danilowicz 1997, Mcllwain 2002). However this is not always the case, especially for fish with short planktonic durations like damselfish where spawning patterns are preserved in the subsequent settlement of the same species (Robertson et al. 1988, Meekan et al. 1993). Furthermore, the theory that larval behaviour plays a major role in shaping replenishment patterns is becoming increasingly difficult to ignore as ongoing research on the swimming ability of larvae suggests they are competent swimmers capable of actively dispersing over large distances during their time in the plankton (Leis \& Carson-Ewart 1997, Stobutski \& Bellwood 1997, Bellwood \& Fisher 2001).

Traditionally, resolving spatial patterns in larval supply was often achieved at the expense of temporal resolution (Doherty \& Williams 1988). This sacrifice is no longer necessary with the development of the techniques described earlier, which are designed to sample concurrently over large spatial scales. Several data sets now exist which explore the interaction between space and time in governing distribution patterns of larval fish nearing settlement (Milicich 1992, Thorrold et al. 1994a,c, Thorrold \& Williams 1996, Dufour et al. 1996, Sponaugle \& Cowen 1996). Not surprisingly, given that these studies cover 4 geographic regions, the spatial coherency of larval replenishment varies enormously. Some found a high degree of synchrony among replicate traps or nets separated by less than $1.5 \mathrm{~km}$, but discovered this pattern did not hold at the within-reef scale (Milicich \& Doherty 1994, Thorrold et al. 1994c). In contrast, Dufour et al. (1996), although unable to comment on small-scale synchrony because of lack of replication, showed for most taxa that the numbers of larvae arriving to the entire coastline of Moorea Island were similar. Likewise, spatial distributions of clupeid and apogonid larvae were found to be similar across a $50 \mathrm{~km}$ latitudinal transect on the Great Barrier Reef shelf (Thorrold \& Williams 1996).

When the primary objective of a study is to measure patterns of larval replenishment, the choice of technique is dependent on the question being asked and the physical conditions of the study sites (Choat et al. 1993). All techniques have limitations. Light traps are most effective in areas with low tidal movement and high water clarity, but are species selective and give only relative estimates of abundance (Doherty 1987, Thorrold 1993, Brogan 1994, Milicich 1994, Sponaugle \& Cowan 1996a). Channel nets are designed to operate specifically in deep tidal channels and require constant water flow (Shenker et al. 1993, Thorrold et al. 1994a,b, Kingsford \& Finn 1997). Crest nets require a shallow reef crest with a uni-directional flow of water (Dufour \& Galzin 1993, Dufour et al. 1996, Doherty \& McIlwain 1997). The advantage of the latter 2 techniques over light traps and visual census is that they sample a greater diversity of larvae especially of those considered reef-associated (Thorrold et al. 1994b). They are also considered the techniques most likely to return absolute estimates of larval fish entering adult habitat (Doherty \& Mcllwain 1997).

Prior to this study, there had been only one attempt at examining patterns of larval supply to Ningaloo Reef, Western Australia; a small pilot study comparing the abundance of larval fish from light traps and towed plankton nets in Ningaloo lagoon (Williams 1988). Despite intensive sampling around the new moon over $12 \mathrm{mo}$, the total number of larvae collected in the lagoon was extremely low. Therefore, a primary goal of this study was to try and improve the data collection procedure with the use of a more appropriate technique. Previous work established that crest nets, 
specially designed for conditions at Ningaloo and deployed on the reef crest were effective in capturing a rich assemblage of late-stage larval fish (Doherty \& McIlwain 1996). At Ningaloo Reef, larval fish preparing for settlement are transported from the pelagic environment into the lagoon via a unidirectional flow of water through the surf zone and across the reef flat. By locating the nets in a highly turbulent environment like the surf zone, it is assumed that larvae are unable to see the nets and avoid them. Having established the suitability of the crest nets, the aims of this study were to determine the magnitude and timing of larval supply for the most abundant taxa and families of coral reef fish. Specifically, I set out: (1) to compare the magnitude of supply between years for the most abundant families; (2) to identify the periodicity in supply for 25 of the most abundant groups using time series analysis; and (3) to compare the synchrony of supply for some of these groups at 2 spatial scales, $500 \mathrm{~m}$ and $5 \mathrm{~km}$.

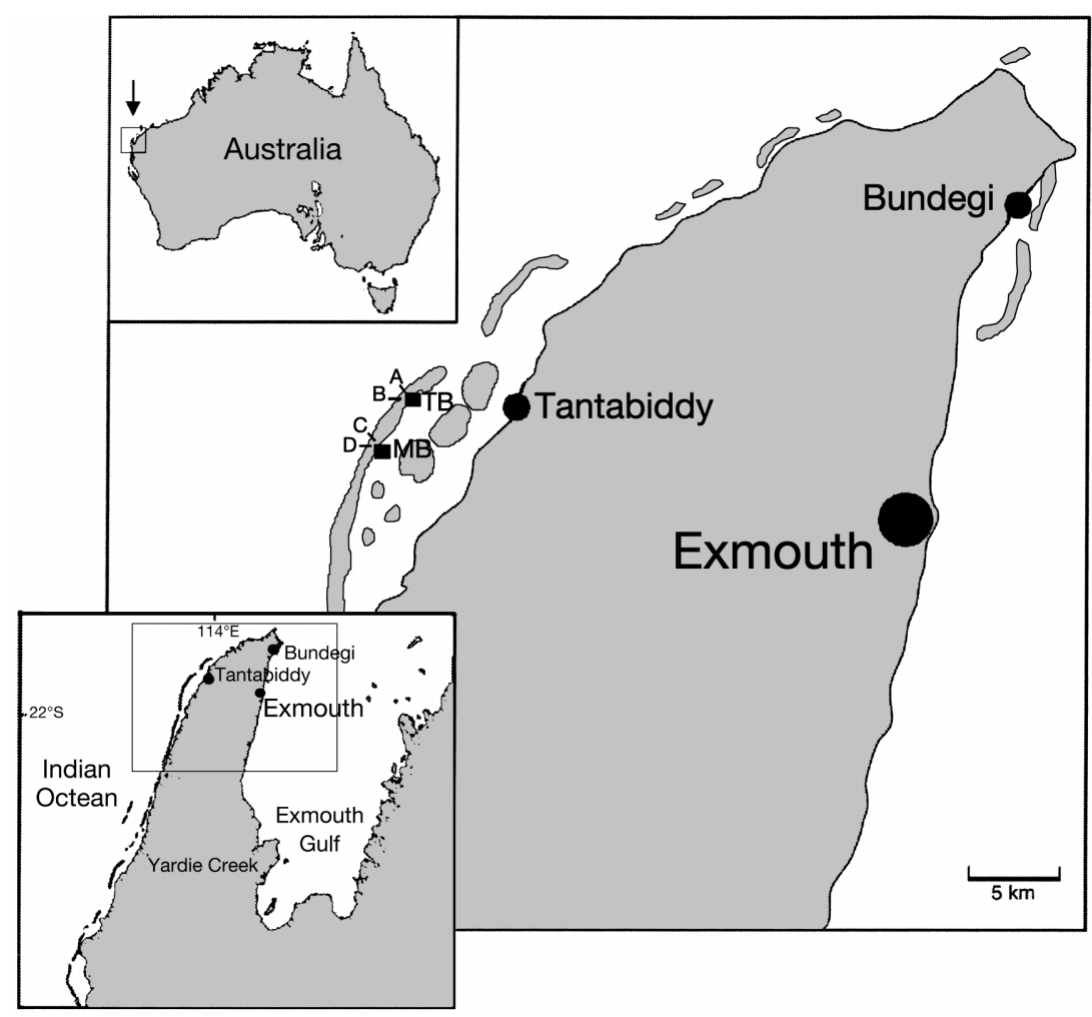

Fig. 1. Crest net locations and their proximity to Tantabiddy and the peninsula, which forms the North West Cape, Western Australia. Nets A and B at Tantabiddy (TB) were deployed in both summers, 1994/1995 and 1995/1996. Nets C and D at Mangrove Bay (MB) were deployed only in the second summer

\section{MATERIALS AND METHODS}

Sampling protocol. Larval supply data were collected in the northern section of Ningaloo Marine Park, Western Australia, for 2 consecutive summers. A full description of the nets used to catch presettlement larvae can be found in Doherty \& Mcllwain (1996). Between 4 October 1994 and 16 March 1995, a pair of crest nets (A and B) were deployed on the shallow reef flat $500 \mathrm{~m}$ apart and approximately $4 \mathrm{~km}$ from the boat ramp at Tantabiddy (Fig. 1, TB). The following year, from 11 November 1995 to 5 March 1996, this net pair was placed in the same location as the first year using GPS co-ordinates. In addition, a second pair of nets (C and D), also positioned $500 \mathrm{~m}$ apart, were deployed $5 \mathrm{~km}$ to the south adjacent to Mangrove Bay (Fig. 1, MB). A total of 94 nights were sampled in the first year and 101 in the second. The nets were emptied every day between 08:00 and 10:00 h and the samples preserved in 5\% formalin in seawater for subsequent identification. Larval fish were separated from crustaceans as well as other invertebrates and algae also caught in the net, and then placed into family categories according to Leis \& Rennis (1983) and Leis \& Trnski (1989). In this study, I define a taxon based on dif- ferences in morphological characteristics. Damaged larvae, which accounted for $<1 \%$ of the total catch, were not included in the data analysis.

Data analysis. The larval supply data were analysed using time-series techniques including spectral analysis, cross-correlation and auto-correlation analyses using STATISTICA. For spectral analysis, the minimum requirement is that data sets must be at least 4 times the length of the period being investigated (Chatfield 1980). To fulfil this requirement, the 2 seasons of sampling were concatenated by disregarding the sampling effort in the first year before 1 November 1994 and after 14 January 1995, and joining it to the second year time series. The complete series ended on 3 February 1996 giving a total of $146 \mathrm{~d} ; 62 \mathrm{~d}$ in the first year and $84 \mathrm{~d}$ in the second year. For periods when no data were collected, the missing data were interpolated from 5 adjacent points (e.g. Milicich 1994). This technique assumes there is serial dependency in the time series, which was confirmed with auto-correlation plots.

Once the data set was concatenated, non-stationarity was removed by transforming the data using $\ln (x+1)$ (Meekan 1992). Following transformation, ARIMA (autoregressive integrated moving average) models were 
then fitted to the data to remove serial dependency (e.g. $1,1,0)$. In most cases where the autocorrelation coefficients decayed slowly, first order differencing was required, keeping in mind that over-differenced series can produce unstable coefficient estimates. The numbers of auto (AR) and moving average (MA) parameters were determined beforehand by inspecting the autocorrelation plots. When the number of parameters was decided and the model fitted to the series, the reliability of the model was confirmed by re-examining the autocorrelation plot to ensure that the serial dependency had been removed. The residuals, computed from the ARIMA model, were used in the spectral analysis.

To detect cycling in larval supply, spectral analysis using the periodiogram approach was employed (Milicich 1992, Thorrold et al. 1994a). Cycles in larval arrival were identified, where peaks in concentration within the time series represent the position within the lunar cycle where replenishment was greatest (Thorrold et al. 1994a). Smoothing of the series in order to 'tame' white noise (which may obscure meaningful periodic cycles) was achieved using the Hamming Window technique. Then potential cycles from the periodiograms (spectral analysis output) were compared with auto-correlation plots of the untransformed data for more accurate signs of cycling (Milicich 1992, Thorrold et al. 1994a). Significance levels were set at 2 times the standard error of the residuals.

Cross-correlation techniques were used to compare larval supply at 2 spatial scales; $500 \mathrm{~m}$ and $5 \mathrm{~km}$. Data were transformed and ARIMA models fitted with the residuals used in the analysis. To compare supply over $5 \mathrm{~km}$, only data from the second summer was used. Daily catch data from the 2 net pairs were pooled (A + $\mathrm{B}=$ Tantabiddy and $\mathrm{C}+\mathrm{D}=$ Mangrove Bay) and then cross-correlated. The length of the time series for this analysis was 85 nights when all 4 nets were operational. To compare supply over $500 \mathrm{~m}$, data from each net for each night were correlated with data from the other net in the pair (Nets A1 and B1, first summer; Nets A2 and B2, Nets C and D, second summer).

Spectral analysis was performed on the 25 most abundant taxa/families. For 5 families (Apogonidae, Gobiidae, Labridae, Blennidae and Pomacentridae), the analysis was done on the most abundant taxa within that family. For the remaining 20 families, the data were pooled across all taxa. The antennariids were not included in the spectral analysis because of low abundance in the first year. For the cross-correlation analysis comparing larval supply over $5 \mathrm{~km}$, the Nemophini, Omobranchini and Salarini blennies were removed. A further 3 groups were removed for the cross-correlation analysis comparing abundance over $500 \mathrm{~m}$; scorpaenids, tripterygiids, and Plectroglyphididon spp.

\section{RESULTS}

\section{Total catch}

In total, over the 2 seasons, 89598 larval fish from 65 families/groups were caught in the nets (Table 1) with only 37 fish unable to be identified to the family level (Table 1). There were fewer larvae caught in the second summer compared to the first. The 2 nets deployed in 1994/1995 yielded 1.7 times higher overall catch (56602) than the 4 nets deployed the following year (32996). Of the 65 families represented in the total catch, 57 were found in 1994/1995 and 60 in 1995/1996. The 5 most abundant families included the Gobiidae, Labridae, Apogonidae, Blennidae and the Lutjanidae/Serranidae group. All 5 showed a dramatic drop in abundance from 1994/1995 to 1995/ 1996.

\section{Total catch between years}

Fig. 2 compares the proportion of the total catch for each family between years (e.g. the 2 nets, A and B, that operated in both summers) and within a year (e.g. the 4 nets from the same summer). Nets A and B caught a greater number of larval fish than the same nets the following summer with few exceptions (the antennariids and pseudochromids). Families like the lutjanids, tetraodontids and tripterygiids were almost entirely absent from the catch in the second summer.

In the second summer, Nets A and B, which were in place in the first year, caught fewer fish than Nets $C$ and D placed at Mangrove Bay. For nearly $50 \%$ of the families, Net B caught more fish than Net A. Only the less abundant families like the scorpaenids and mullids were more abundant in Net A. Of the Mangrove Bay nets, Net D caught more fish than Net C, which was $500 \mathrm{~m}$ away. This result was consistent among all 20 families.

\section{Temporal patterns}

From the spectral analysis of 25 of the most abundant families/taxa, 5 potential patterns were identified; lunar, <30 d, semi-lunar, >30 d and stochastic (Table 2). Data from 6 of the 25 families/taxa were graphed with abundance, periodiogram and auto-correlation function plots to illustrate the range of periodicity in larval supply found at Ningaloo; blenny 2, labrid 1, Soleidae, leptocephali, Omobranchini blenny and goby 2 (Figs. 3, 4 \& 5)

Semi-lunar periodicity was the most common pattern with 10 of the 25 taxa having peaks in larval supply 
every 2 wk (Table 2). Blenny 2 had the most consistent semi-lunar pattern with the periodiogram revealing a strong peak at $15.1 \mathrm{~d}$ (Fig. 3). This was confirmed from the auto-correlogram plot with significant peaks at 15 and $30 \mathrm{~d}$. The arrival of the most abundant labrid (labrid 1) was semi-lunar, with peaks on the periodio- gram at $15 \mathrm{~d}$, and significant peaks on the ACF plot at 16 and $30 \mathrm{~d}$, respectively (Fig. 3). The synodontids were the only other taxa to have both significant semilunar peaks on the ACF plots and the periodiograms (Table 2). The remaining 7 taxa demonstrating semilunar periodicity had peaks at $15 \mathrm{~d}$ on the periodio-

Table 1. Total number of larvae captured in crest nets deployed during 2 consecutive summers, 1994/1995 and 1995/1996, at Ningaloo Reef, Western Australia. Abundance values were pooled across families. ${ }^{a}$ Problems with initial identification meant larvae belonging to the families Lutjanidae and Serranidae were pooled and called Lutjanidae/Serranidae, and ${ }^{\mathrm{b}}$ those belonging to

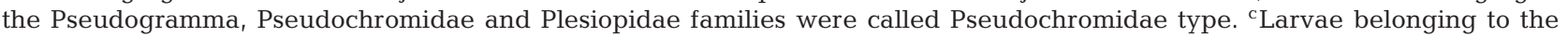
Leptocephali are from both Elopiformes and Anguilliformes. * Rare taxa which are represented by less than or equal to a total of 5 individuals in either year

\begin{tabular}{|c|c|c|c|c|c|c|c|c|c|}
\hline \multirow[t]{2}{*}{ Taxa } & \multicolumn{2}{|c|}{ 1994/1995 } & \multicolumn{2}{|c|}{ 1995/1996 } & \multirow[t]{2}{*}{ Taxa } & \multicolumn{2}{|c|}{ 1994/1995 } & \multicolumn{2}{|c|}{ 1995/1996 } \\
\hline & Total & $\%$ & Total & $\%$ & & Total & $\%$ & Total & $\%$ \\
\hline Elopiformes & & & & & Leiognathidae* & 0 & 0 & 5 & 0.015 \\
\hline Albulidae* & 5 & 0.008 & 13 & 0.039 & Lethrinidae & 546 & 0.965 & 425 & 1.290 \\
\hline Anguilliformes & & & & & Lutjanidae/Serranidae $^{a}$ & 3648 & 6.447 & 272 & 0.824 \\
\hline Congridae $^{*}$ & 1 & 0.002 & 6 & 0.143 & Malacanthidae & 31 & 0.055 & 35 & 0.106 \\
\hline Ophichthidae & 11 & 0.019 & 16 & 0.048 & Mullidae & 96 & 0.170 & 46 & 0.139 \\
\hline Clupeiformes & & & & & Nemipteridae & 6 & 0.011 & 7 & 0.021 \\
\hline Clupeidae & 64 & 0.113 & 13 & 0.039 & Pempheridae* & 1 & 0.002 & 7 & 0.021 \\
\hline Siluriformes & & & & & Pomacanthidae & 8 & 0.014 & 8 & 0.024 \\
\hline Siluriformes & 52 & & & & Pomacentridae & 961 & 1.698 & 763 & 2.312 \\
\hline PIotosidae & 52 & 0.092 & 0 & 0 & Priacanthidae* & 4 & 0.007 & 9 & 0.027 \\
\hline Myctophiformes & & & & & Pseudochromidae type & 1964 & 3.469 & 688 & 2.085 \\
\hline Synodontidae & 466 & 0.823 & 457 & 1.138 & Sciaenidae* ${ }^{*}$ & 21 & 0.037 & 4 & 0.012 \\
\hline Ophidiiformes & & & & & Terapontidae* & 9 & 0.016 & 3 & 0.009 \\
\hline Carapidae* & 3 & 0.005 & 2 & 0.006 & Mugilidae & 205 & 0.362 & 142 & 0.430 \\
\hline Batrachoidiformes & & & & & Sphyraenidae & 45 & 0.080 & 35 & 0.106 \\
\hline Batrachoididae & 16 & 0.028 & 51 & 0.155 & Labridae & 10902 & 19.262 & 8071 & 24.461 \\
\hline & & & & & Scaridae & 152 & 0.269 & 775 & 2.349 \\
\hline $\begin{array}{l}\text { Lophiiformes } \\
\text { Antennariidae }\end{array}$ & & & & & Mugiloididae & 30 & 0.053 & 17 & 0.052 \\
\hline Antennariidae & 96 & 0.169 & 2685 & 8.138 & Blennidae & 2891 & 5.109 & 2616 & 7.929 \\
\hline Gobiesociformes & & & & & Tripterygiidae & 839 & 1.483 & 207 & 0.627 \\
\hline Gobiesocidae* & 15 & 0.027 & 1 & 0.003 & Schindleriidae & 116 & 0.205 & 0 & 0 \\
\hline Cyprinodontiformes & & & & & Callionymidae & 18 & 0.032 & 34 & 0.103 \\
\hline Exocoetidae & 19 & 0.033 & 35 & 0.106 & Gobiidae & 26141 & 46.201 & 8914 & 27.016 \\
\hline Hemiramphidae* & 4 & 0.007 & 2 & 0.006 & Microdesmidae* & 4 & 0.007 & 59 & 0.179 \\
\hline Pegasiformes & & & & & Acanthuridae & 22 & 0.039 & 52 & 0.158 \\
\hline Pegasidae* & 4 & 0.007 & 5 & 0.015 & Siganidae & 47 & 0.083 & 222 & 0.673 \\
\hline Sygnathiformes & & & & & Scombridae* & 4 & 0.007 & 7 & 0.021 \\
\hline Aulostomidae* & 1 & 0.002 & 0 & 0 & Pleuronectiformes & & & & \\
\hline Fistularidae & 31 & 0.055 & 30 & 0.091 & Psettodidae ${ }^{*}$ & 4 & 0.007 & 0 & 0 \\
\hline Solenostomidae* & 1 & 0.002 & 1 & 0.003 & Bothidae & 452 & 0.799 & 1357 & 4.113 \\
\hline Sygnathidae & 56 & 0.099 & 27 & 0.082 & Pleuronectidae* & 74 & 0.131 & 3 & 0.009 \\
\hline Dactylopteriformes & & & & & Cynoglossidae* & 2 & 0.003 & 9 & 0.027 \\
\hline Dactylopteridae* & 0 & 0 & 2 & 0.006 & Soleidae & 207 & 0.366 & 71 & 0.215 \\
\hline Scorpaeniformes & & & & & Tetraodontiformes & & & & \\
\hline Scorpaenidae & 156 & 0.276 & 276 & 0.836 & Ostracidae & 6 & 0.011 & 10 & 0.031 \\
\hline Platycephalidae & 41 & 0.072 & 43 & 0.130 & Diodontidae & 16 & 0.028 & 26 & 0.079 \\
\hline Perciformes & & & & & Monocanthidae & 91 & 0.161 & 132 & 0.400 \\
\hline $\begin{array}{l}\text { Apogonidae } \\
\text { Aprormes }\end{array}$ & 5279 & 9.330 & 3293 & 9.980 & Tetraodontidae & 158 & 0.279 & 16 & 0.048 \\
\hline Carangidae & 42 & 0.074 & 11 & 0.033 & Leptocephali $^{\mathrm{c}}$ & 507 & 0.896 & 923 & 2.798 \\
\hline Cepolidae* $^{*}$ & 0 & 0 & 2 & 0.006 & & & & & \\
\hline Chaetodontidae & 9 & 0.016 & 7 & 0.021 & Unknown & 2 & 0.003 & 35 & 0.106 \\
\hline Gerreidae* & 1 & 0.002 & 0 & 0 & $\mathbf{T}$ & 5 & 100 & 6 & 100 \\
\hline Haemulidae & 0 & 0 & 11 & 0.033 & & & 100 & & 100 \\
\hline Kyphosidae* & 0 & 0 & 1 & 0.003 & Total groups & 57 & & 60 & \\
\hline
\end{tabular}




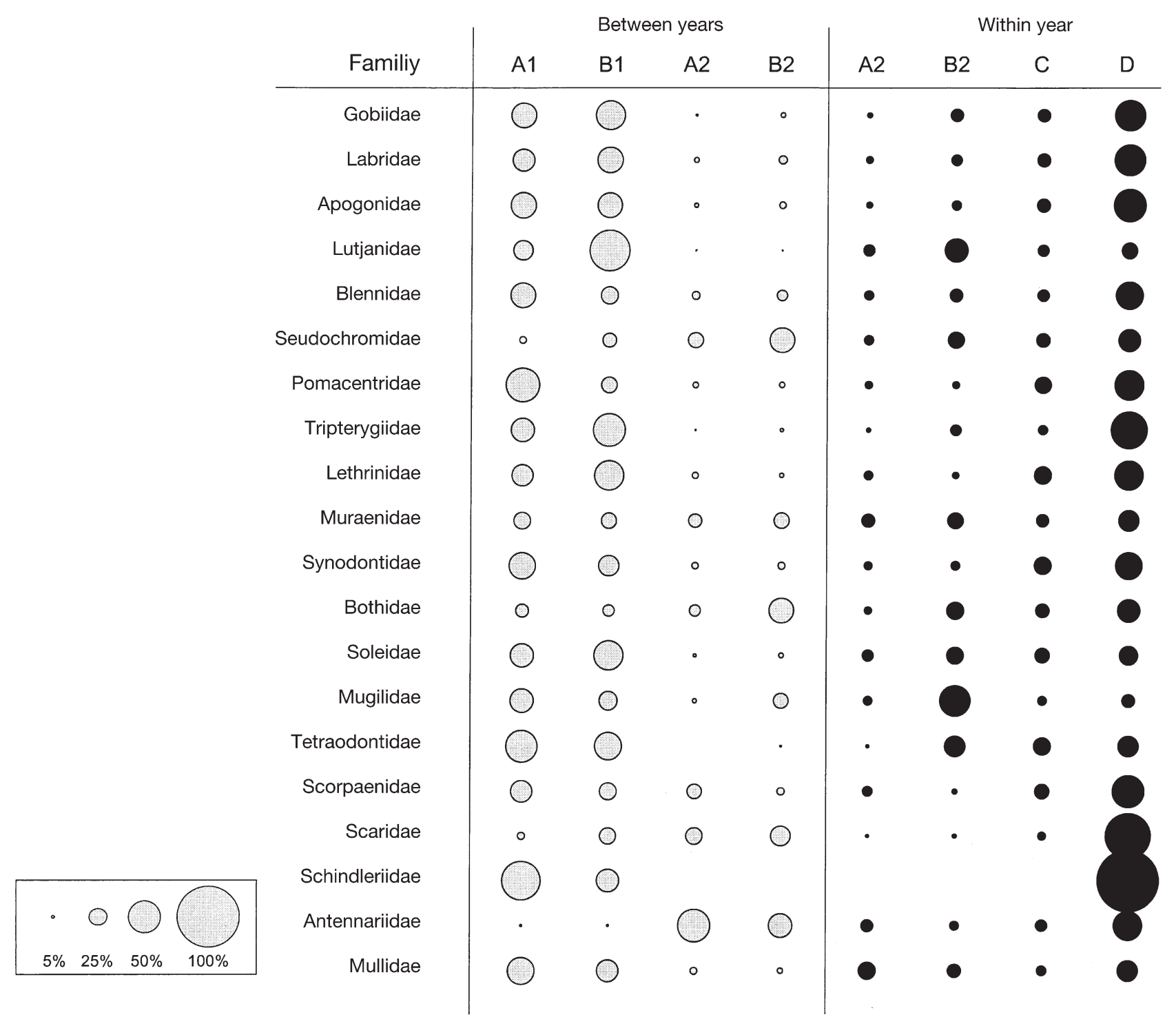

Fig. 2. Comparison of the proportion of larval fish caught between years (grey circles) and within a year (black circles) for the 20 most abundant families. The sum across the circles in each comparison is $100 \%$; Nets A1, B1, A2 and B2 (grey circles); Nets A2, $\mathrm{B} 2, \mathrm{C}$ and D (black circles). The relative size of the circles is given in the bottom left-hand corner of the plot

grams but weak, non-significant peaks on the ACF plots. These included goby 1, apogon 5, Pomacentrus coelestis, Plectroglyphididon spp., tripterygiids, scarids and scorpaenids (Table 2 ).

The replenishment of the soles and lethrinids cycled at a period less than the length of a lunar month (Fig. 4, Table 2). Although the soles showed a strong peak at $27 \mathrm{~d}$, the ACF plot showed significant activity around 20 to 23 d (Fig. 4B). The Blenniini and apogon 8 also showed peaks on the periodiograms at less than $30 \mathrm{~d}$; however, both were not significant on the autocorrelograms (Table 2).

The leptocephali showed the strongest evidence of lunar cycling with a strong peak at $27 \mathrm{~d}$ (Fig. 5), which was confirmed on the auto-correlogram with a significant peak at $30 \mathrm{~d}$ (Table 2). Other taxa with lunar patterns included Pomacentrus vaiuli, bothid 5 and the siganids (Table 2). All of these had significant activity at $30 \mathrm{~d}$ on the ACF plots except bothid 5 .

The remaining taxa showed either cycling at longer than $30 \mathrm{~d}$ (e.g. Omobranchini, Salarini blennies) or stochastic patterns (e.g. goby 2, labrid 10, apogon 21, Nemophini blennies) (Table 2). For the Omobranchini blennies, the periodiogram showed peaks at 12, 27 and $45 \mathrm{~d}$ (Fig. 5). However, the significant activity on the ACF plot at 40 to $42 \mathrm{~d}$ confirmed that this group is arriving at periods greater than the lunar cycle. The distribution of the auto-correlogram for goby 2 shows a 
slow exponential decay beginning at lag 1 (Fig. 5). This is indicative of random patterns or white noise with no obvious periodicity and is confirmed in the periodiograms where no one peak is dominant.

\section{Spatial patterns}

To compare larval arrival over a distance of $5 \mathrm{~km}$, 23 taxa were subject to cross-correlation analysis (Table 3). Cross-correlation plots are presented for 4 taxa/families with significant peaks at a lag of $0 \mathrm{~d}$ (apogonid 5, bothid 5, Scorpaenidae and Antennariidae) and the leptocephali which had a significant peak at a lag of $1 \mathrm{~d}$ (Fig. 6). The rarity of apogon 5 in the catch could explain why there was a significant peak at a lag of $0 \mathrm{~d}$. Of the $9 \mathrm{~d}$ it was caught in the nets at Tantabiddy, it appeared in the Mangrove Bay nets for $3 \mathrm{~d}$ (Fig. 6A).
Other groups that showed consistent but non-significant patterns in arrival times between the 2 sites included the scorpaenids and the antennariids. Although peaks in antennariid abundance did not occur until after the new moon in December 1995, they were synchronous between Tantabiddy and Mangrove Bay (Fig. 6D). Finally, the arrival of leptocephali larvae at both sites was correlated but lagged by $1 \mathrm{~d}$. Peaks in abundance at the Tantabiddy nets occurred $1 \mathrm{~d}$ earlier than at Mangrove Bay (Fig. 6E).

To compare larval arrival over the smaller scale of $500 \mathrm{~m}$, I performed cross-correlation analysis on 19 of the 23 taxa analysed for the $5 \mathrm{~km}$ spatial scale (Table 4). A selection of the significant results is presented in Fig. 7. For most of the 19 taxa, there was a significant correlation with at least 1 net pair, and often more than one. For example, apogonid 8, siganids and pseudochromid type had significant correla-

Table 2. Lunar periodicities of the 25 most abundant taxa analysed using spectral analysis. Period, results of periodiogram; ACF, results from the autocorrelation function plots; ${ }^{*}$ : significant at $2 \times \mathrm{SE}_{i}{ }^{\text {ns: }}$, non significant at $2 \times \mathrm{SE}^{* *}$ : results plotted in Figs. 3, 4 \& 5

\begin{tabular}{|c|c|c|c|c|c|c|c|c|c|}
\hline \multirow[t]{2}{*}{ Taxa } & \multicolumn{2}{|c|}{ Semi-lunar } & \multicolumn{2}{|c|}{$<30 \mathrm{~d}$} & \multicolumn{2}{|c|}{ Lunar } & \multicolumn{2}{|c|}{$>30 \mathrm{~d}$} & \multirow[t]{2}{*}{ Stochastic } \\
\hline & Period & $\mathrm{ACF}$ & Period & $\mathrm{ACF}$ & Period & $\mathrm{ACF}$ & Period & $\mathrm{ACF}$ & \\
\hline \multicolumn{10}{|l|}{ Gobidae } \\
\hline Goby 1 & 14,34 & $14-15^{\mathrm{ns}}, 30-32^{\mathrm{ns}}$ & & & & & & & \\
\hline Goby $2^{* *}$ & & & & & & & & & $\mathrm{x}$ \\
\hline \multicolumn{10}{|l|}{ Labridae } \\
\hline Labrid $1^{* *}$ & 15 & $16^{*}, 30^{*}$ & & & & & & & \\
\hline Labrid 10 & & & & & & & & & $\mathrm{x}$ \\
\hline \multicolumn{10}{|l|}{ Apogonidae } \\
\hline apogon 21 & & & & & & & & & $\mathrm{x}$ \\
\hline apogon 5 & 15 & & & & & & & & \\
\hline apogon 8 & & & 19 & $19^{\text {ns }}$ & & & & & \\
\hline \multicolumn{10}{|l|}{ Blennidae } \\
\hline Blenniini & & & 13 & $11-13^{\mathrm{ns}}$ & & & & & \\
\hline Blenny $2^{* *}$ & 15 & $16^{*}, 30^{*}$ & & & & & & & \\
\hline Nemophini & & & & & & & & & $\mathrm{x}$ \\
\hline Omobranchini** & & & & & & & 45 & $39^{*}$ & \\
\hline Salarini & & & & & & & 45 & $42-43^{*}$ & \\
\hline \multicolumn{10}{|l|}{ Pomacentridae } \\
\hline Pomacentrus coelestis & 15,34 & $15-16^{\mathrm{ns}}, 31-32^{\mathrm{ns}}$ & & & & & & & \\
\hline Plectroglyphidion spp. & 15,34 & $15-16^{\mathrm{ns}}, 31-32^{\mathrm{ns}}$ & & & & & & & \\
\hline Pomacentrus vaiuli & & & & & 15 & $30^{*}$ & & & \\
\hline Tripterygiidae & 15 & $14-15^{\mathrm{ns}}, 27^{\mathrm{ns}}$ & & & & & & & \\
\hline Lethrinidae & & & 23 & $22-25^{\mathrm{ns}}$ & & & & & \\
\hline Leptocephali** & & & & & 27 & $30^{*}$ & & & \\
\hline Synodontidae & 15 & $15^{*}, 29-32^{*}$ & & & & & & & \\
\hline \multicolumn{10}{|l|}{ Bothidae } \\
\hline Bothid 5 & & & & & 34 & $29^{\mathrm{ns}}$ & & & \\
\hline Soleidae ${ }^{* *}$ & & & 8,277 & $7^{*}, 23-26^{*}$ & & & & & \\
\hline Scaridae & 15 & $15^{\mathrm{ns}}$ & & & & & & & \\
\hline Siganidae & & & & & 34 & $30^{*}$ & & & \\
\hline Pseudochromidae type & & & & & & & & & $\mathrm{x}$ \\
\hline Scorpaenidae & 15,22 & $14,26^{\mathrm{ns}}$ & & & & & & & \\
\hline
\end{tabular}


tions between all 3 net pairs. When comparing the net pair that operated in both years (Nets A and B), 9 of the groups had significant correlations in both years. Both of these results suggest that it was a regular occur-
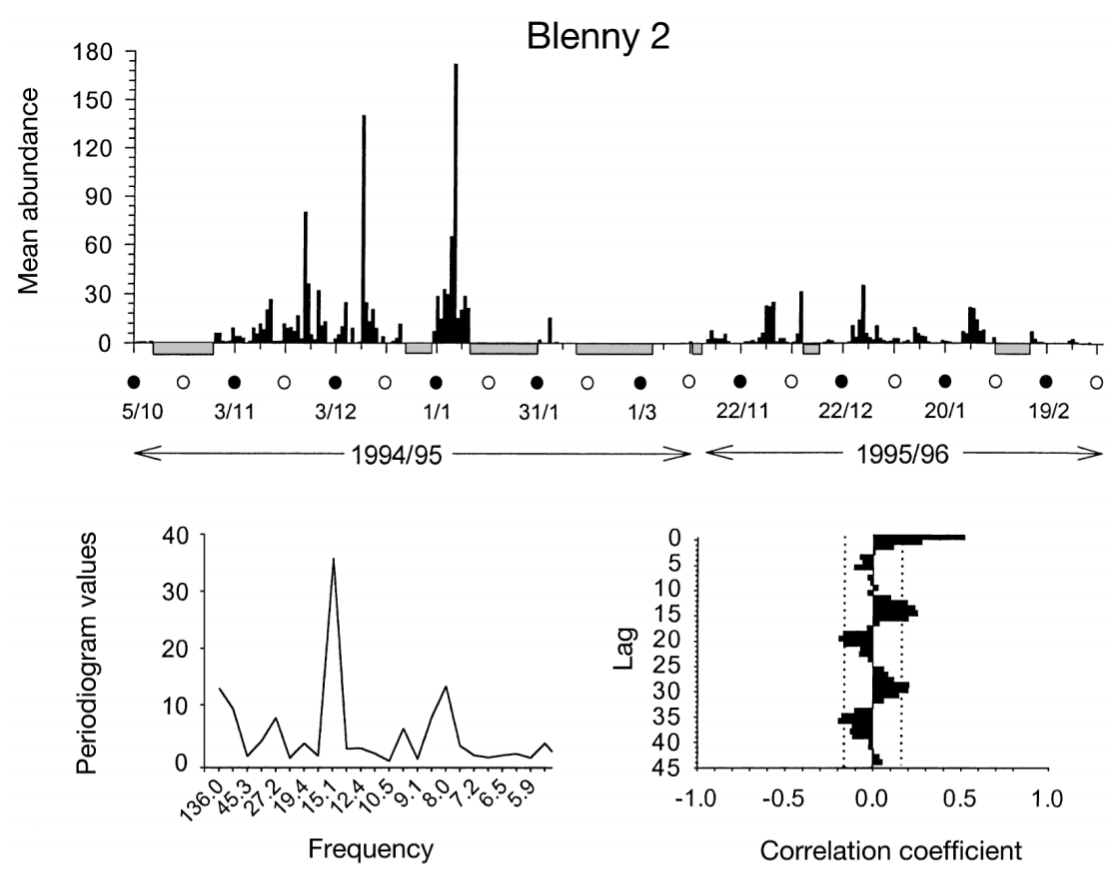

Labrid 1
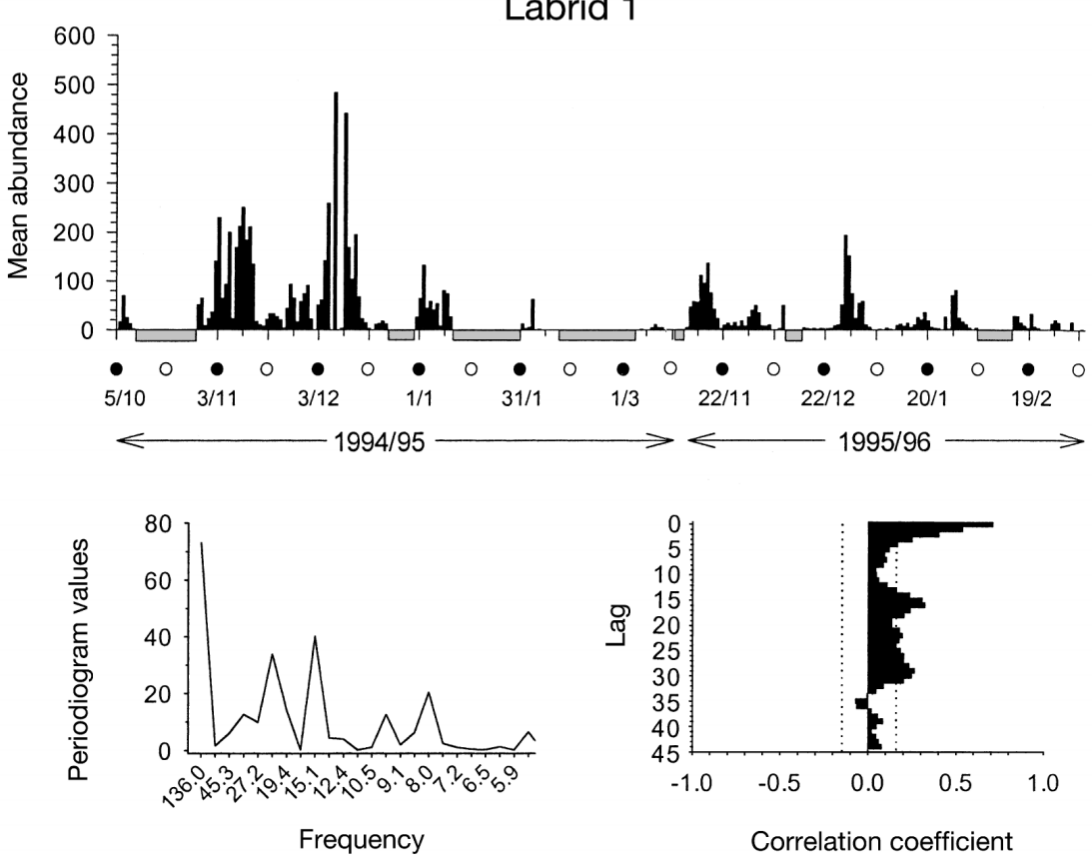

Fig. 3. (Upper panels) Time series of blenny 2 and labrid 1 larvae in the crest nets from 5 October 1994 to 5 March 1996. The 2 year have been concatenated. Grey bars on $x$-axis are missing data points. New moon (•); full moon (o). (Lower left) Periodiogram plot of transformed data $(\ln [x+1])$ identifying the cycling within the time series. (Lower right) ACF plot of the raw data where the vertical lines are $2 \times \mathrm{SE}$ rence for a lot of the abundant larvae to cross the reef crest at Ningaloo Reef in patches of at least $500 \mathrm{~m}$ wide. Conversely, the leptocephali larvae, which showed significant correlations in arrival over $5 \mathrm{~km}$ at a lag of $1 \mathrm{~d}$ (Fig. 6E), showed only a slightly significant correlation with one of the pairs of nets; Nets C and D (Table 4).

\section{DISCUSSION}

Deploying modified plankton nets on the reef crest at Ningaloo Reef proved to be successful in catching large numbers of larval reef fish. The diversity of the catch was extremely high and included both reef associated and nonreef associated species rarely seen in such abundance as larvae. More than $85 \%$ of the families caught in the nets were common to both summers, despite the significant inter-annual decline in larval abundance from the first to the second summer by as much as $100 \%$, for the more abundant groups, such as the gobies and apogonids. Within both years, catches were larger during early austral summer in the months of November, December and January, and lower in October, February and March; a pattern consistent across taxa. Only a few taxa (such as blenny 2) showed strong cyclic patterns of arrival with most arriving consistently on a semi-lunar cycle. Other taxa, such as the bothids and leptocephali, peaked during the new moon periods. Spatial patterns in larval replenishment differed according to taxa/family group. In the second summer, many groups like the goby 2, labrid 10 and apogonid 5 arrived in similar numbers to sites spaced $5 \mathrm{~km}$ apart. For the net pairs that were spaced $500 \mathrm{~m}$ apart, $95 \%$ of the taxa analysed showed significant correlations in abundance at this scale.

\section{Temporal patterns in larval supply}

Temporal patterns of larval supply to Ningaloo Reef varied enormously with many fish cueing into moon phase and 
others appearing to settle at random. The synchronous arrival of presettlement fish with different moon phases can be attributed to 2 sources; adult spawning behaviour (Robertson 1991) or larval behaviour (Thorrold et al. 1994b). For some species of reef fish, the timing (but not magnitude) of the delivery of larvae has been directly linked with peaks in spawning effort preceding the recruitment event (Robertson et al. 1988, Meekan et al. 1993). This implies that adult spawning routines may be scheduled to coincide with periods that are optimal for the larvae's return to the reef (Robertson 1991). Conversely, for damselfish species like Dascyllus albisella and $P$. vaiuli and other larvae with an extended residency in the plankton (e.g. labrids), this link has been shown to be weak (Hunt von Herbing \& Hunte 1991, Danilowicz 1997, Robertson et al. 1999, Mcllwain 2002). This suggests that in the latter cases, observed settlement patterns for some coral reef fishes are probably a direct result of larval behaviour in the plankton, particularly towards the later stages of development.

Many studies, from different localities worldwide, have shown that peaks in settlement patterns for a large number of coral reef fish families occur close to the new moon (Robertson et al. 1988, Milicich 1992, Thorrold et al. 1994a, Dufour et al. 1996, Sponaugle \& Cowen 1996, Caselle \& Warner 1996). Victor (1991) suggests that the adaptive significance behind this inherent behaviour involves avoidance of nocturnal predators. This is supported by the prevalence of lunar cycling among different families and across oceans (Thorrold et al. 1994a). Rates of predation probably decline during periods of moonless nights resulting in increased larval survivorship (McFarland et al. 1985), although few studies have directly tested this idea (Thorrold et al. 1994a). This tendency towards colonisation during moonless nights was clearly a strategy undertaken by many, but not all, larval fish arriving to Ningaloo Reef and was not family specific. A number of taxa from the same family, such as the blennies and apogonids, displayed dichotomous patterns in arrival from semilunar to stochastic. In contrast, different taxa with entirely different morphological characteristics, such as the synodontids and labrids, arrived at similar times near the quarter moons. The leptocephali and bothids are 2 examples where replenishment patterns are similar for some families at different locations. In the

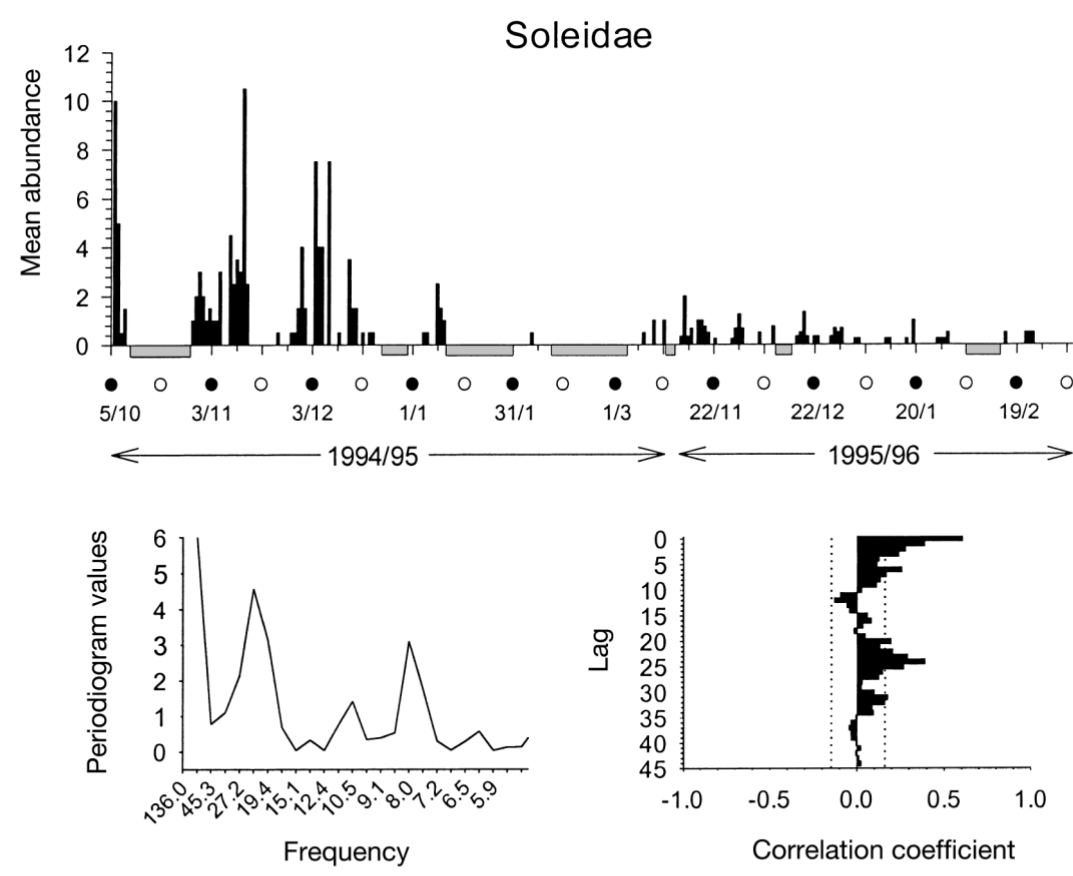

\section{Leptocephali}
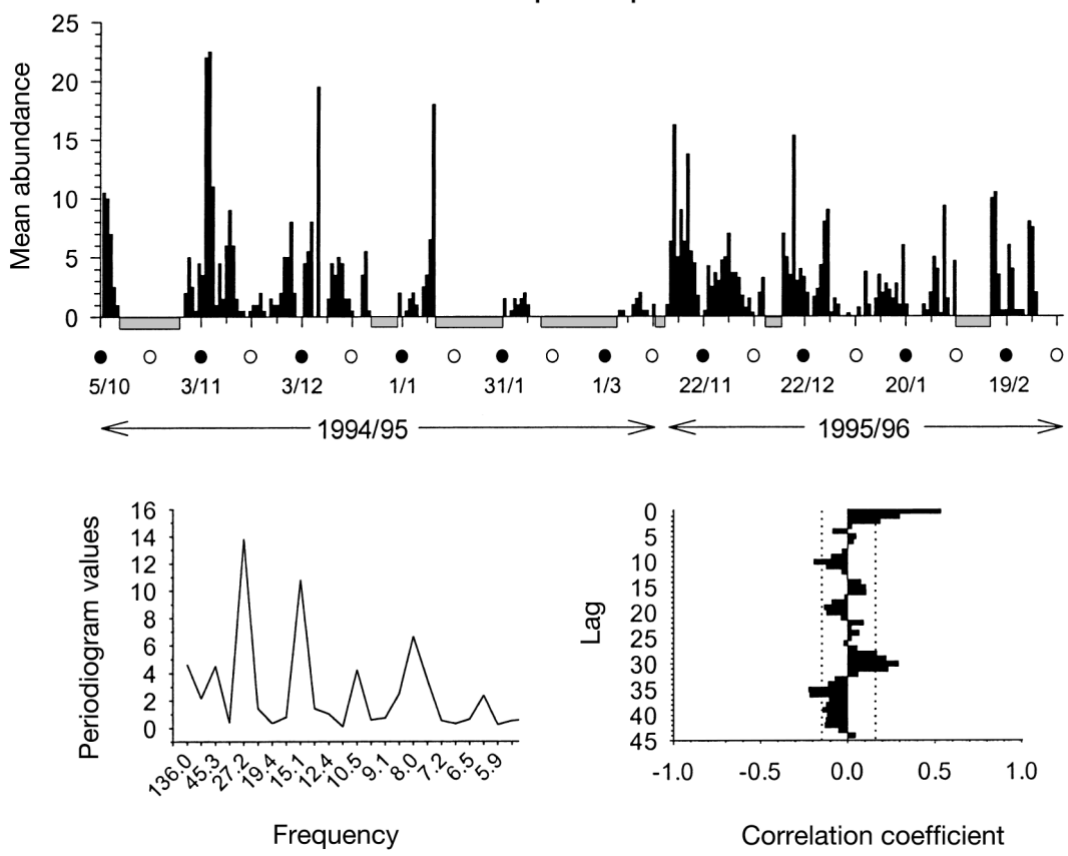

Fig. 4. Time series of Soleidae and Leptocephali larvae in the crest nets. Graph format follows that of Fig. 3 

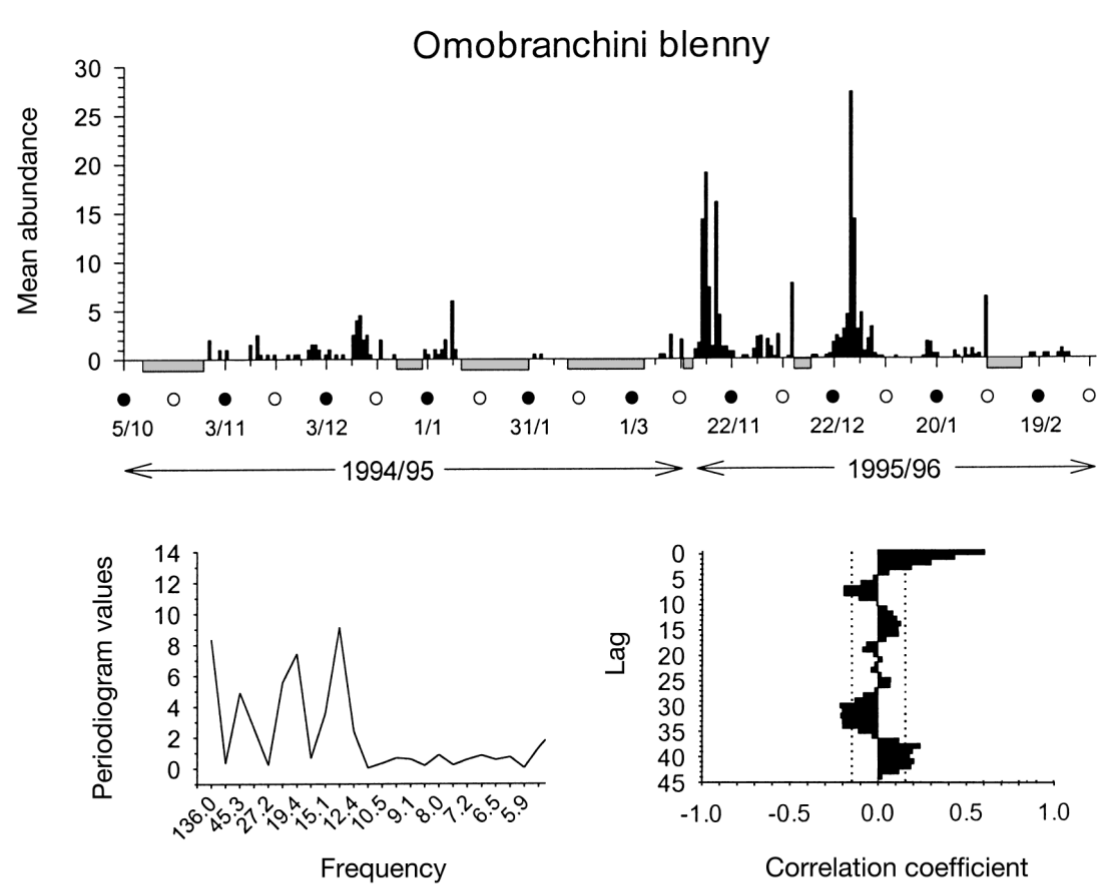

Goby 2

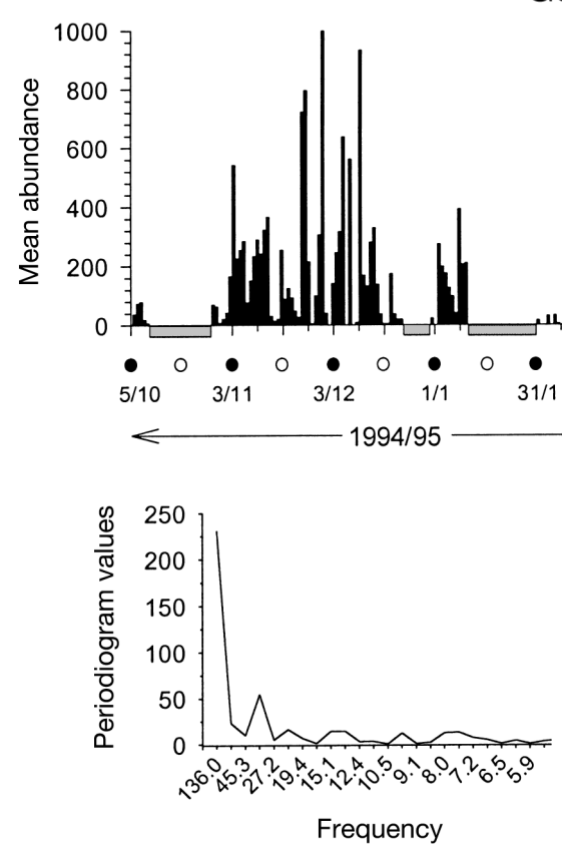

Fig. 5. Time series of Omobranchini blennies and goby 2 larvae in the crest nets. Graph format follows that of Fig. 3

Bahamas, where leptocephali larvae were caught in large numbers during winter, patterns of replenishment were similar to Ningaloo, with most of the activity occurring around the new moon. The bothids also arrived around the new moon at these 2 locations, with another flatfish species, Bothus pantherinus, showing similar patterns in Tahiti (Dufour et al. 1996).
As well as similarities across locations there are plenty of examples where the same families exhibited different patterns of replenishment. The blennies, one of the most commonly caught larval fish in both light traps and nets, show variable replenishment patterns at all locations studied to date. Five blenny types arrived around the third quarter moon in Barbados, although the timing for one of these Ophioblennius atlanticus varied between years (Sponaugle \& Cowen 1996a). The summer assemblage of blennies in the Bahamas was weakly correlated to the new moon along with wind and current patterns (Thorrold et al. 1994b). A similar pattern was found at Lizard Island, eastern Australia, where blennies showed almost no relationship with the lunar cycle (Milicich \& Doherty 1994). At Ningaloo, the 5 blennies analysed showed very different replenishment patterns. Two of these, Omobranchini and Salarini blennies, had similar periodicities of 42 to $45 \mathrm{~d}$, although they have been shown to have very different vertical distributions within the plankton; the Omobranchini preferring shallow water and the Salarini preferring deeper water (Leis 1991). Like the blennies, the synodontids also had variable replenishment patterns between locations. In Barbados, peaks in Synodus intermedius occurred approximately $5 \mathrm{~d}$ before the new moon (Sponaugle \& Cowen 1996a), whereas in Tahiti and Ningaloo, peaks in the synodontids occurred either after the new moon (Tahiti; Dufour et al. 1996) or every $14 \mathrm{~d}$ (Ningaloo).

The Pomacentridae were another family that also showed significant differences in the replenishment patterns at different locations. One pomacentrid species from Barbados, Stegastes partitus had peaks in arrival between 19 and 21 d (Sponaugle \& Cowen 1996a,b); whereas $S$. nigricans in Tahiti peaked on Days 4 and 6 of the lunar cycle (Dufour et al. 1996). In Australia, the arrival of the common pomacentrid Pomacentrus coelestis differed between the west and east coasts. At Lizard Island on the east coast, the peaks in abundance for $P$. coelestis occurred after the new moon in the back 
Table 3. Results of the cross-correlation analysis, which compares daily abundance of 23 of the most abundant taxa captured in nets from 2 sites, $5 \mathrm{~km}$ apart. The comparisons are the pooled abundance of Nets A and B at Mangrove Bay and Nets C2 and D2 at Tantabiddy. The data presented are for $1995 / 1996$ only. Total length of time series $=80 \mathrm{~d}$. Values are correlation coefficients presented when larval supply is lagged by $-1,0$ and $1 \mathrm{~d}^{*}{ }^{*}$ : significant at $2 \times \mathrm{SE}_{;}{ }^{* *}$ : results plotted in Fig. 6

\begin{tabular}{|c|c|c|c|}
\hline \multirow{2}{*}{ Taxa } & \multicolumn{3}{|c|}{$\operatorname{Lag}(\mathrm{d})$} \\
\hline & -1 & 0 & 1 \\
\hline \multicolumn{4}{|l|}{ Gobiidae } \\
\hline Goby 1 & -0.16 & 0.19 & 0.11 \\
\hline Goby 2 & -0.20 & $0.83^{*}$ & -0.08 \\
\hline \multicolumn{4}{|l|}{ Labridae } \\
\hline Labrid 1 & -0.06 & $0.33^{*}$ & 0.09 \\
\hline Labrid 10 & -0.22 & $0.79^{*}$ & 0.01 \\
\hline \multicolumn{4}{|l|}{ Apogonidae } \\
\hline Apogonid 21 & $-0.27^{*}$ & $0.38^{*}$ & 0.17 \\
\hline Apogonid $5^{* *}$ & -0.12 & $0.81^{*}$ & -0.13 \\
\hline Apogonid 8 & $0.33^{*}$ & $0.70^{*}$ & $-0.37^{*}$ \\
\hline \multicolumn{4}{|l|}{ Blennidae } \\
\hline Blenny 2 & -0.04 & $0.70^{*}$ & 0.03 \\
\hline \multicolumn{4}{|l|}{ Pomacentridae } \\
\hline P. coelestis & $-0.25^{*}$ & $0.39^{*}$ & -0.02 \\
\hline Plectroglyphididon spp. & -0.09 & 0.11 & -0.08 \\
\hline$P$. vaiuli & 0.14 & $0.51^{*}$ & 0.07 \\
\hline Tripterygiidae & $0.53^{*}$ & -0.11 & 0.02 \\
\hline Lethrinidae & 0.13 & $0.46^{*}$ & -0.001 \\
\hline Leptocephali $^{* *}$ & 0.02 & -0.03 & $0.51^{*}$ \\
\hline Synodontidae & -0.16 & 0.09 & $0.25^{*}$ \\
\hline \multicolumn{4}{|l|}{ Bothidae } \\
\hline Bothid $5^{* *}$ & -0.18 & $0.56^{*}$ & -0.09 \\
\hline Soleidae & -0.18 & 0.12 & 0.09 \\
\hline Scaridae & -0.06 & $0.68^{*}$ & -0.09 \\
\hline Antennariidae ${ }^{* *}$ & $-0.22^{*}$ & $0.35^{*}$ & $0.23^{*}$ \\
\hline Siganidae & $-0.28^{*}$ & 0.04 & -0.1 \\
\hline Pseudochromidae type & $-0.21^{*}$ & $0.26^{*}$ & -0.02 \\
\hline Scorpaenidae** & -0.13 & $0.40^{*}$ & -0.09 \\
\hline
\end{tabular}

reef and before the new moon in the front-reef habitat (Milicich 1992, Milicich \& Doherty 1994). In contrast, peaks in larval $P$. coelestis at Ningaloo occurred every $14 \mathrm{~d}$ and was synchronous over $5 \mathrm{~km}$.

The overall peak in larval abundance at Ningaloo occurred from November to January with fewer fish caught as the summer progressed. Although no systematic sampling took place outside the October to March period, I did conduct a visual census of $0+$ juveniles of a number of reef fish species at several locations along the length of Ningaloo Reef in September 1994. The lack of new settlers during this census suggests that settlement of reef fish in winter is probably negligible and that like the Great Barrier
Table 4. Results of the cross-correlation analysis, which compares daily abundance of 19 taxonomic groupings captured in net pairs $500 \mathrm{~m}$ apart. The data presented are for Nets A1 and B1 (1994/1995) and Nets A2 and B2 and Nets C and D (1995/1996). Total length of time series varies according to the year. Values are correlation coefficients presented when larval supply is lagged by $0 \mathrm{~d} .^{*}$ : significant at $2 \times \mathrm{SE}_{i}$ ${ }^{* *}$ : results plotted in Fig. 7. ns: non-significant

\begin{tabular}{|c|c|c|c|}
\hline Taxa & $\mathrm{A} 1$ and B1 & $\begin{array}{c}\text { Nets } \\
\text { A2 and B2 }\end{array}$ & C and D \\
\hline \multicolumn{4}{|l|}{ Gobiidae } \\
\hline Goby 1 & ns & ns & ns \\
\hline Goby $2^{* *}$ & 0.61 & 0.79 & $\mathrm{~ns}$ \\
\hline \multicolumn{4}{|l|}{ Labridae } \\
\hline Labrid 1 & 0.65 & 0.49 & ns \\
\hline Labrid 10 & $\mathrm{~ns}$ & $\mathrm{~ns}$ & 0.27 \\
\hline \multicolumn{4}{|l|}{ Apogonidae } \\
\hline Apogonid 21 & 0.54 & 0.46 & $\mathrm{~ns}$ \\
\hline Apogonid 5 & $\mathrm{~ns}$ & 0.93 & $\mathrm{~ns}$ \\
\hline Apogonid 8 & 0.46 & 0.79 & 0.23 \\
\hline \multicolumn{4}{|l|}{ Blennidae } \\
\hline Blenny 2 & 0.25 & 0.24 & $\mathrm{~ns}$ \\
\hline \multicolumn{4}{|l|}{ Pomacentridae } \\
\hline P. coelestis ${ }^{* *}$ & 0.86 & ns & 0.37 \\
\hline P. vaiuli & 0.53 & 0.38 & $\mathrm{~ns}$ \\
\hline Lethrinidae $^{* *}$ & 0.78 & $\mathrm{~ns}$ & 0.33 \\
\hline Leptocephali & $\mathrm{ns}$ & $\mathrm{ns}$ & 0.23 \\
\hline Synodontidae & ns & 0.57 & $\mathrm{~ns}$ \\
\hline \multicolumn{4}{|l|}{ Bothidae } \\
\hline Bothid $5^{* *}$ & 0.34 & 0.79 & $\mathrm{~ns}$ \\
\hline Soleidae & 0.52 & ns & ns \\
\hline Scaridae & ns & 0.71 & ns \\
\hline Antennariidae & 0.30 & $\mathrm{~ns}$ & 0.31 \\
\hline Siganidae & 0.28 & 0.67 & 0.51 \\
\hline Pseudochromidae type ${ }^{* *}$ & 0.31 & 0.79 & 0.56 \\
\hline
\end{tabular}

Reef on the east coast, the summer period is when fish replenishment peaks at Ningaloo. Two concurrent studies that quantified larval supply to a tropical coral reef during the winter months found a similar result (Thorrold et al. 1994a,c). In winter, the assemblage of larval fish to Lee Stocking Island was dominated by a completely different suite of families (with the exception of clupeids) compared with that of the summer period. The most abundant winter larvae were the leptocephali, which accounted for less than $1 \%$ of the total catch in summer. As well as a different larval assemblage, there were 5 times fewer fish caught in winter compared to the summer. In a similar study using light-traps, Wilson (2001) found that although settlement occurred throughout the year, there were significantly greater catches of larval fish during the wet season compared to the drier months. 
(a)

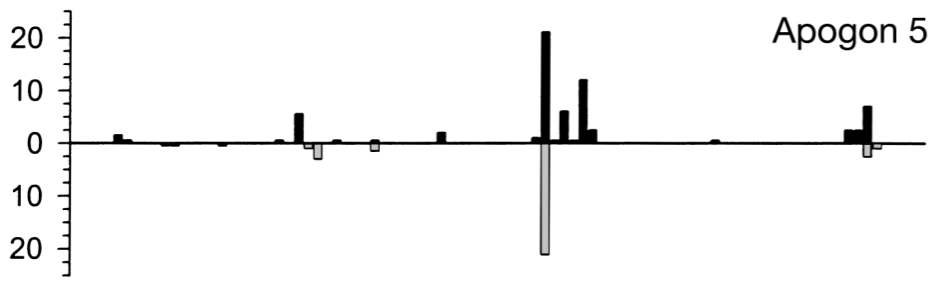

(b)

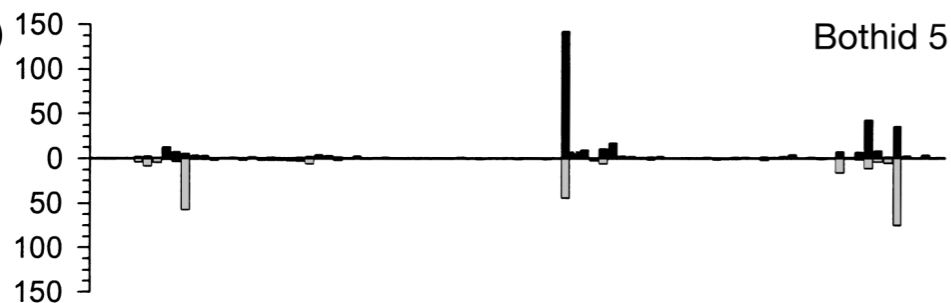

(c)

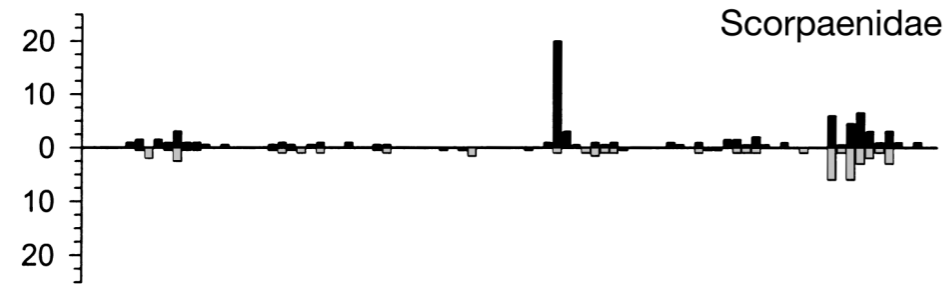

(d) 80
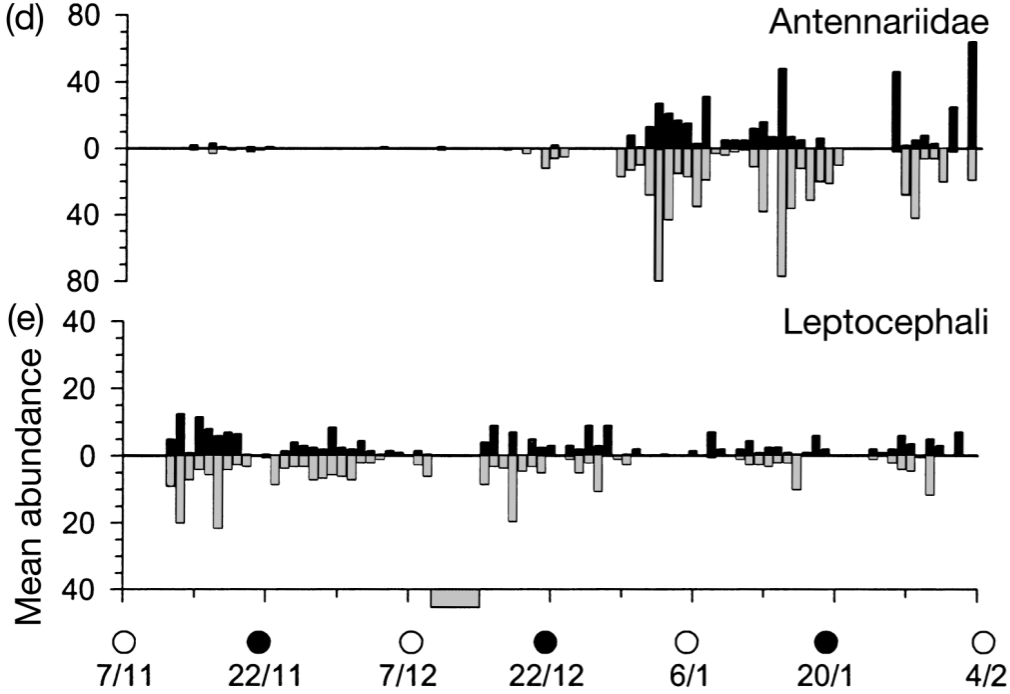
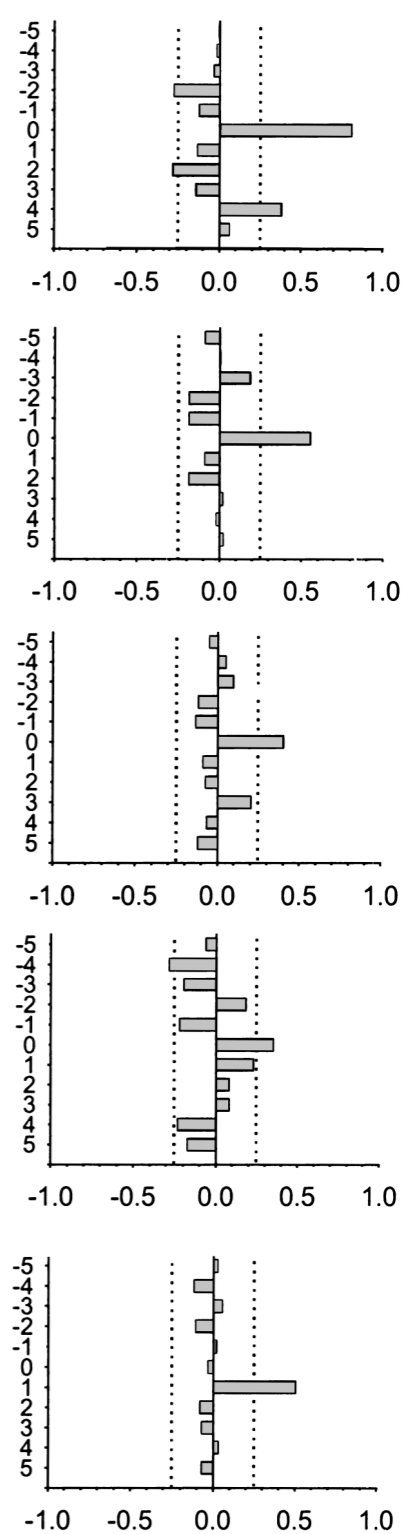

Fig. 6. Comparison of the mean abundance of larvae caught in the crest nets for 5 different taxa/families (a to e) during 1995/1996 only. Upper bars are Mangrove Bay (Nets C and D) and lower bars are Tantabiddy (Nets A2 and B2). Total length of time series is

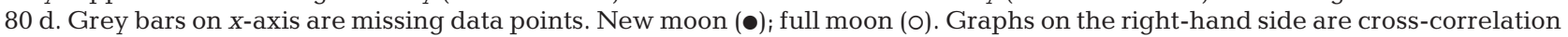
function plots of larval abundance between the 2 sites, Mangrove Bay and Tantabiddy, $5 \mathrm{~km}$ apart. Table 3 presents the r-values from the cross-correlation analysis for each taxa

\section{Spatial patterns in larval supply}

The spatial pattern of replenishment to Ningaloo differed according to both taxa and scale. Most of the abundant groups showed significant spatial coherency between Mangrove Bay and Tantabiddy (distance of $5 \mathrm{~km}$ ), although taxa belonging to the same family, like the gobies, sometimes showed very different results. Goby 2 for example had a highly significant relationship between the 2 sites, whereas the less abundant goby 1 showed a weak relationship. In contrast the 3 apogonid taxa were significantly correlated over the same scale. At Lizard Island, 3 different habitats were sampled using light traps; a shallow backreef bay, exposed front reef and deep lagoon habitat (Milicich \& Doherty 1994). Two summers of sampling 
showed a dramatic increase in the abundance of larvae entering the back-reef habitat from the first to second year. This inter-annual change in replenishment meant the relationship between each of the habitats also changed, from being weakly synchronised during periods of low supply to a strong synchrony as numbers of fish increased. Furthermore, several taxa consistently chose the exposed front reef over the back reef, despite an increase in abundance to the latter habitat in the second year. Although strong synchrony would suggest meso-scale patches kilometres wide, additional work found oceano- graphic processes explained some of the variability between habitats (Milicich 1994).

The observed differences between sites for some taxa were unlikely to be a result of habitat selection prior to settlement seen elsewhere (Milicich \& Doherty 1994, Doherty et al. 1996, Wilson 2001). The uniform shape of the reef crest at Ningaloo and the similarity in orientation for at least $90 \mathrm{~km}$ (see Fig. 1) suggests there is little difference in habitat type from one site to the next, like those described for Lizard Island. Because of the homogenous nature of the reef front, larvae approaching the reef crest in preparation for settle-

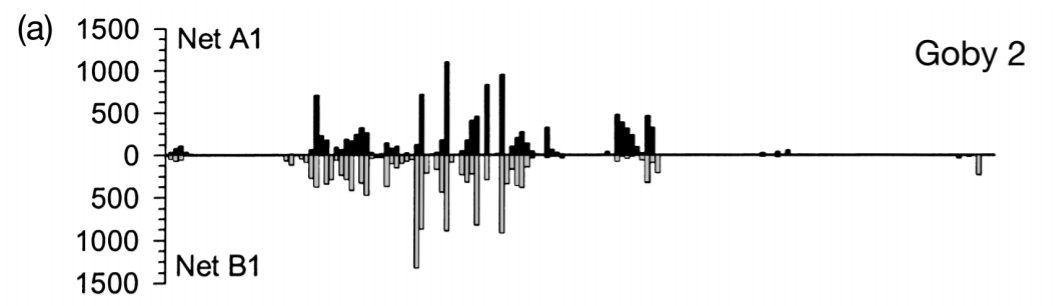

(b)
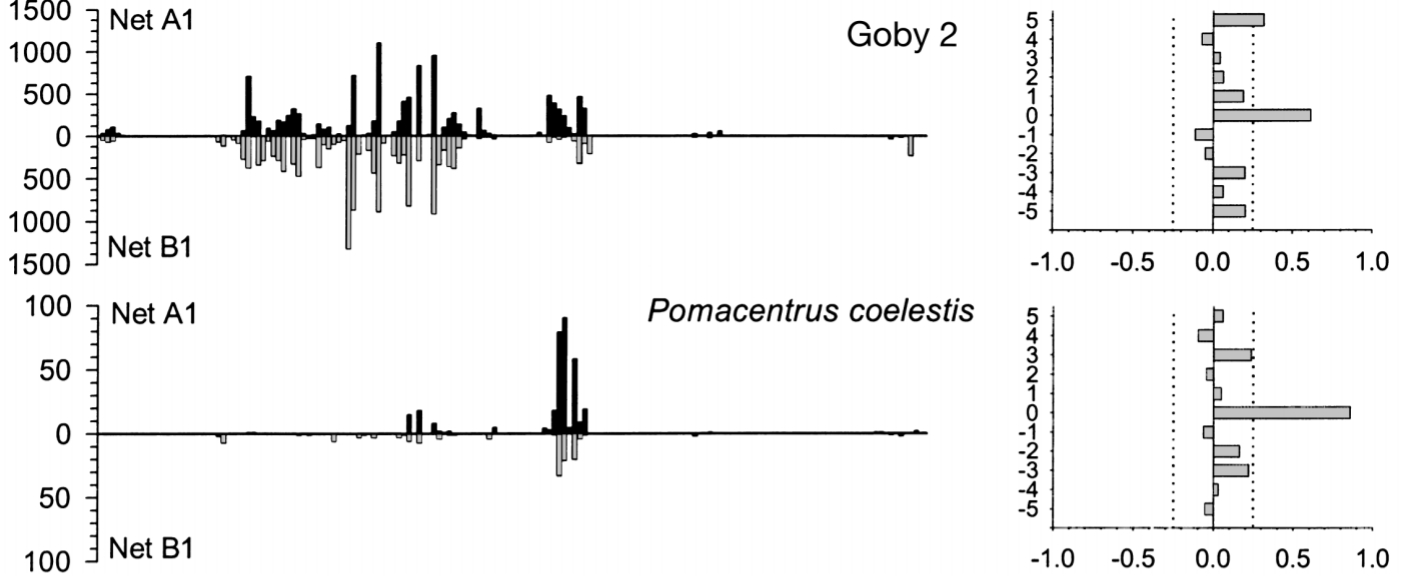

(c)
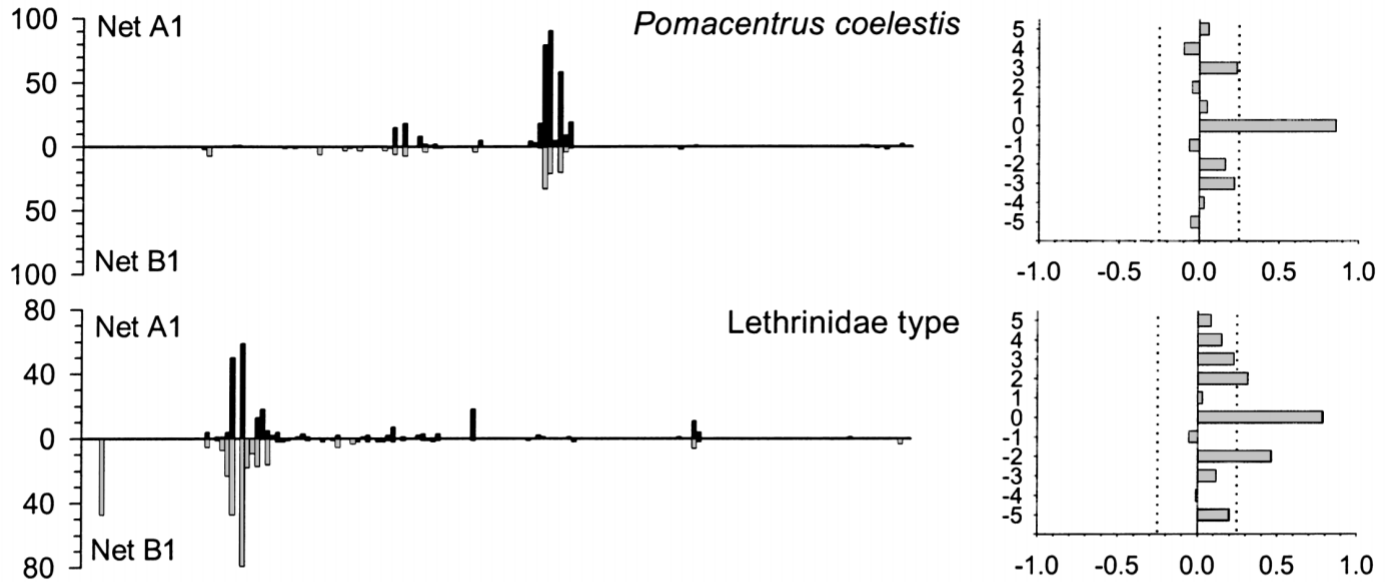

(d)
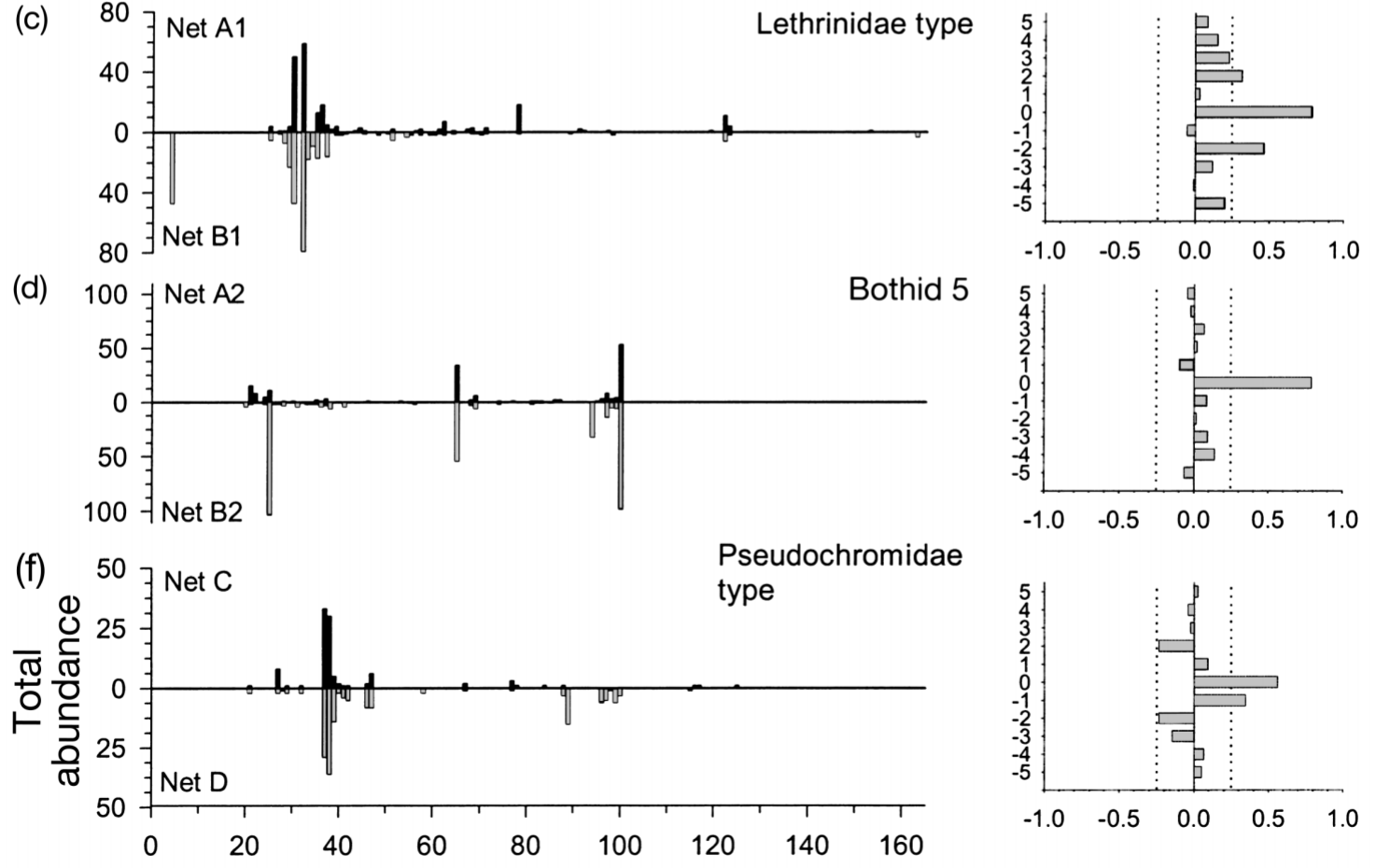

Fig. 7. Comparison of the total abundance of larvae caught in the crest nets for 5 different taxa/families (a to e) during 1994/1995 and 1995/1996. The $x$-axis or lunar day has been standardised so that Day 0 represents the first d of the new moon period in October of both years. Gaps in $x$-axis are missing data points. Graphs on the right-hand side are cross-correlation function plots of larval abundance between net pairs, $500 \mathrm{~m}$ apart. Table 4 presents the r-values from the cross-correlation analysis for each taxa 
Table 5. Summary of the number of larval fish taxa captured using various techniques at a number of geographic locations worldwide. Effort is expressed as either the number of days or months during which sampling took place. M: moored nets; RC: reef crest nets. The list is in order of greatest number to least number of taxa recorded for each study

\begin{tabular}{|c|c|c|c|c|c|}
\hline Geographic location & Site & Method & Effort & Number of taxa & Source \\
\hline West Pacific Ocean & GBR (Lizard Island) & LT, Nets & $5 \mathrm{~d}$ & 70 & Choat et al. $(1993)^{a}$ \\
\hline West Pacific Ocean & GBR (One Tree Is.) & Nets (M) & $61 \mathrm{~d}$ & 66 & Kingsford \& Finn (1997) \\
\hline East Indian Ocean & Ningaloo & Nets (RC) & $190 \mathrm{~d}$ & 65 & This study \\
\hline Caribbean Sea & Bahamas & Nets (M) & $\sim 150 \mathrm{~d}$ & 58 & Thorrold et al. (1994c) \\
\hline Caribbean Sea & Bahamas & Nets (M) & $79 \mathrm{~d}$ & 53 & Thorrold et al. (1994a) \\
\hline Central Pacific Ocean & Tahiti & Nets (RC) & $8 \mathrm{mo}$ & 50 & Dufour \& Galzin (1993) ${ }^{\mathrm{b}}$ \\
\hline Central Pacific Ocean & Tahiti & Nets (RC) & $\sim 50 \mathrm{~d}$ & 46 & Dufour et al. (1996) \\
\hline West Pacific Ocean & GBR (Townsville) & Light trap & $3 \mathrm{mo}$ & 36 & Thorrold \& Williams $(1996)^{a, b}$ \\
\hline West Pacific Ocean & GBR (Lizard Island) & Light trap & $126 \mathrm{~d}$ & 35 & Milicich (1992) \\
\hline East Pacific Ocean & Mexico & Light trap & $5 \mathrm{mo}$ & 31 & Brogan $(1994)^{a, b}$ \\
\hline Caribbean Sea & Barbados & Light trap & $\sim 130 \mathrm{~d}$ & 31 & Sponaugle \& Cowen (1996b) \\
\hline West Pacific Ocean & GBR (One Tree Is.) & Nets (RC) & $5 d$ & 25 & Doherty \& McIlwain (1996) \\
\hline West Pacific Ocean & GBR (Lizard Island) & Light trap & $25 \mathrm{~d}$ & 18 & Doherty (1987) \\
\hline Central Pacific Ocean & Tuamotu & Light trap & $3 \mathrm{~d}$ & 13 & Leis et al. $(1998)^{b}$ \\
\hline
\end{tabular}

ment would be unable to distinguish between suitable sites and avoid certain habitat. This homogeneity suggests that the production of chemical or auditory stimuli that larval fish use as cues for settlement (Sweatman 1988, Tolimieri et al. 2000), may be of a similar intensity over a relatively large spatial scale, although this remains to be tested. Large-scale patches of larvae in the nearshore waters would be subject to settlement cues at the same time, which would explain the strong correlation between the abundance of larvae at sites separated by $5 \mathrm{~km}$ for taxa like goby 2, apogonid 5 and labrid 10. The assembly of large numbers of larval fish in the water adjacent to the reef crest at Ningaloo, just before sunset, has been documented previously (McIlwain 1997). Aggregating facilitates the rapid, active transport of larvae across the reef crest into juvenile habitat in the lagoon. Families, such as the blennies and scarids, with consistent nocturnal patterns of arrival across several nights were found to have some degree of control in the timing of their entry to the lagoon.

Small-scale differences in reef morphology may have contributed to the enormous variation in larval abundance between Mangrove Bay and Tantabiddy during the second summer. Hearn et al. (1986) point out these small differences mean cross-reef water flow along the reef crest is not spatially uniform. Although I spent a considerable amount of time choosing the site for the 2 nets at Mangrove Bay to duplicate the Tantabiddy sites in terms of depth, distance from the reef crest and topography immediately in front of the nets, there were obviously small differences in the physical nature of the site that I was unable to account for. The differences (albeit small) between the 2 sites meant local hydrographic conditions, such as wave height and the speed of water flow across the reef flat, also differed. Future studies that use these crest nets in a similar coral reef setting should try to eliminate any variation between nets by regularly measuring water flow either before the nets are deployed or during their operation.

\section{Comparing Ningaloo with other geographic locations}

Very few previous studies that have examined larval supply to coral reefs surpass the diversity seen at Ningaloo Reef (Table 5). Only Choat et al. (1993) and Kingsford \& Finn (1997) captured a greater number of families (70 and 66, respectively). The former study was a multi-technique approach using various plankton nets (bongo, neuston, tucker and purse-seine) and light traps targeting all the ontogenetic stages rather than specifically the later, presettlement ones. Those studies where diversity was similar to that of Ningaloo also used modified plankton nets moored in either a channel or on the reef crest (Dufour \& Galzin 1993, Thorrold et al. 1994a,c, Kingsford \& Finn 1997). In 2 studies using crest nets, conducted at One Tree Island on the southern Great Barrier Reef, deployment was for periods of less than 1 mo (Doherty \& McIlwain 1996, Kingsford \& Finn 1997). If the sampling periods at One Tree Island had encompassed the entire recruitment season, an even greater suite of larval fish would probably have been encountered. Similarly in 
Tahiti, greater larval diversity than that published is likely as Dufour et al. (1996) classified and counted less than $2 \%$ of the total catch.

The choice of technique largely determines the larval assemblage caught (see Table 5). Of the techniques available light traps, channel nets and crest nets are the most successful in catching large numbers of presettlement fish entering coral reef habitats. Although many reef species are represented in light traps, the catch tends to be dominated by fish that are predominantly phototactic (Doherty 1987, Milicich 1988). This includes groups like the clupeids and atherinids (Milicich 1992, Thorrold \& Williams 1996), which are deemed pelagic rather than reef associated because they lack a benthic juvenile stage (Thorrold et al. 1994a). A recent study in the Caribbean found more than $85 \%$ of the light-trap catch comprised non-reef species that were not included in the analysis of the data set (Wilson 2001). On the other hand, some groups that are non-phototactic are never present in light-trap samples. Choat et al. (1993), in a comparison of towed nets and light traps, found that families, such as the callyionymids, carangids and lutjanids, were present in relatively large numbers in samples from towed bongo nets. These 3 families, although present in the plankton, were not captured in the light traps deployed at the same time and location as the nets. Leptocephali are another group found in abundance in fixed nets (Thorrold et al. 1994c, this study) but rarely cited as being caught in a light trap. Because the principle behind light traps is to act as an attractant, they do not catch a true representation of the presettlement fish approaching a reef and should only be considered in situations where crest or channel nets cannot be deployed.

\section{CONCLUSION}

The results of this study show that there are a number of similarities in the timing of larval replenishment to fringing reefs of Western Australia (Ningaloo Reef) and the Great Barrier Reef on the East Coast (e.g. Lizard Island; Meekan 1992, Milicich 1992). Peaks in larval supply at the 2 locations were similar, occurring predominantly in the austral summer months. Periodicity in larval replenishment was found to occur at both locations, although not surprisingly this was largely taxon and family specific. This work also confirmed the incredible range of adaptive behaviours utilised by multi-species reef fish assemblages as they make their transition from a larval stage to adulthood. Future research should continue to build on our understanding of replenishment patterns using similar techniques to those used at Ningaloo. If the chosen location fits the criteria for the deployment of nets, they should be the preferred technique to measure diversity and replenishment patterns of coral reef fish larvae. Although larval supply data are often logistically difficult and expensive to collect, the results are extremely worthwhile and give an excellent insight into small-scale temporal and spatial trends rarely seen in classical fisheries literature.

Acknowledgements. Thanks to the many volunteers who made the data collection for this study possible, and to Peter Doherty and Bob Black for their constructive criticism. This manuscript benefited from discussions and/or reviews by Andrew Halford and Arnold Sutterlin. This research was supported by the Australian Institute of Marine Science (AIMS) and the University of Western Australia (UWA). This is AIMS Publication No. 1112.

\section{LITERATURE CITED}

Bellwood DR, Fisher R (2001) Relative swimming speeds in reef fish larvae. Mar Ecol Prog Ser 211:299-303

Brogan MW (1994) Two methods of sampling fish larvae over reefs: a comparison from the Gulf of California. Mar Freshw Res 118:33-44

Caselle JE, Warner RR (1996) Variability in recruitment of coral reef fishes: the importance of habitat at 2 spatial scales. Ecology 77:2488-2504

Chatfield C (1980) The analysis of time series: an introduction. Chapman \& Hall, London

Choat JH, Doherty PJ, Kerrigan BA, Leis JM (1993) A comparison of towed nets, puse seine, and light-aggregation devices for sampling larvae and pelagic juveniles of coral reef fishes. Fish Bull 91:195-209

Danilowicz BS (1997) A potential mechanism for episodic recruitment of a coral reef fish. Ecology 78:1415-1423

Doherty PJ (1987) Light-traps: selective but useful devices for quantifying the distributions and abundances of larval fishes. Bull Mar Sci 41:423-431

Doherty PJ (1991) Spatial and temporal patterns in recruitment. In: Sale PF (ed) The ecology of fishes on coral reefs. Academic Press, San Diego, p 261-293

Doherty PJ, McIlwain JL (1996) Monitoring larval fluxes through the surf zones of Australian coral reefs. Mar Freshw Res 47:383-390

Doherty PJ, Williams DM (1988) The replenishment of coral reef fish populations. Oceanogr Mar Biol Annu Rev 26: 487-551

Doherty PJ, Kingsford M, Booth DJ (1996) Habitat selection before settlement by Pomacentrus coelestis. Mar Freshw Res 47:391-399

Dufour V, Galzin R (1993) Colonization patterns of reef fish larvae to the lagoon at Moorea Island, French Polynesia. Mar Ecol Prog Ser 102:143-152

Dufour V, Riclet E, Lo-Yat A (1996) Colonization of reef fishes at Moorea Island, French Polynesia: temporal and spatial variation of the larval flux. Mar Freshw Res 47:413-422

Hearn CJ, Hatcher BG, Masini RJ, Simpson CF (1986) Oceanographic processes on the Ningaloo Coral Reef, Western Australia. University of Western Australia Environmental Dynamics Report. Department of Conservation and Land Management, Perth

Hunt von Herbing I, Hunte W (1991) Spawning and recruit- 
ment of the bluehead wrasse Thalassoma bifasciatum in Barbados, West Indies. Mar Ecol Prog Ser 72:49-58

Kingsford MJ, Finn MD (1997) The influence of phase of the moon and physical processes on the input of presettlement fishes to coral reefs. J Fish Biol 51:176-205

Leis JM (1991) Vertical distribution of fish larvae in the Great Barrier Reef Lagoon, Australia. Mar Biol 109:157-166

Leis JM, Carson-Ewart BM (1997) In situ swimming speeds of the late pelagic larvae of some Indo-Pacific coral reef fishes. Mar Ecol Prog Ser 159:165-174

Leis JM, Rennis DS (1983) The larvae of Indo-Pacific coral reef fishes. New South Wales University Press, Sydney, and University Press, Honolulu

Leis JM, Trnski T (1989) The larvae of Indo-Pacific shore fishes. New South Wales University Press, Sydney, and University Hawaii Press, Honolulu

Leis JM, Trnski T, Doherty PJ, Dufour V (1998) Replenishment of fish populations in the enclosed lagoon of Taiaro Atoll: (Tuamotu Archipelago, French Polynesia) evidence from eggs and larvae. Coral Reefs 17:1-8

McFarland WN, Brothers EB, Ogden JC, Shulman MJ, Bermingham EL, Kotchian-Prentiss NM (1985) Recruitment patterns in young French grunts, Haemulon flavolineatum (family Haemulidae) at St Croix, US Virgin Islands. Fish Bull US 83:413-426

McIlwain JL (1997) Hydrodynamic flows and the flux of larval fishes across the crest of Ningaloo Reef, Western Australia. Proc 8th Int Coral Reef Symp 2:1133-1138

McIlwain JL (2002) Link between reproductive output and larval supply of a common damselfish species, with evidence of replenishment from outside the local population. Mar Ecol Prog Ser 236:219-232

Meekan MG (1992) The influence of pre- and post-settlement processes on the population dynamics of coral reef damselfishes. PhD thesis, Griffith University, Brisbane

Meekan MG, Milicich MJ, Doherty PJ (1993) Larval production drives temporal patterns of larval supply and recruitment of a coral reef damselfish. Mar Ecol Prog Ser 93:217-225

Milicich MJ (1988) The distribution and abundance of presettlement fish in the nearshore waters of Lizard Island. Proc 6th Int Coral Reef Symp, Townsville 2:785-790

Milicich MJ (1992) Light traps: a novel technique for quantifying larval supply and replenishment of coral reef fish populations. PhD thesis, Griffith University, Brisbane

Milicich MJ (1994) Dynamic coupling of reef fish replenishment and oceanographic processes. Mar Ecol Prog Ser 110:135-144

Milicich MJ, Doherty PJ (1994) Larval supply of coral reef fish populations: magnitude and synchrony of replenishment to Lizard Island, Great Barrier Reef. Mar Ecol Prog Ser 110:121-134

Robertson DR (1991) The role of adult biology in the timing of spawning of tropical reef fishes. In: Sale PF (ed) The ecology of fishes on coral reefs. Academic Press, San Diego, CA, p 356-386

Editorial responsibility: Otto Kinne (Editor), Oldendorf/Luhe, Germany
Robertson DR, Green DG, Victor BC (1988) Temporal coupling of production and recruitment of larvae of a Caribbean reef fish. Ecology 69:370-381

Robertson DR, Swearer SE, Kaufman K, Brothers E (1999) Settlement vs. environmental dynamics in a pelagicspawning reef fish at Caribbean Panama. Ecol Monogr 69: 195-218

Shenker JM, Maddox ED, Wishinski E, Pearl A, Thorrold SR, Smith N (1993) Onshore transport of settlement-stage Nassau grouper Epinephelus striatus and other fishes in Exuma Sound, Bahamas. Mar Ecol Prog Ser 98:31-43

Sponaugle S, Cowen RK (1996a) Nearshore patterns of coral reef fish larval supply to Barbados, West Indies. Mar Ecol Prog Ser 133:13-28

Sponaugle S, Cowen RK (1996b) Larval supply and patterns of recruitment for 2 Caribbean reef fishes, Stegastes partitus and Acanthurus bahianus. Mar Freshw Res 47: 433-447

Stobutzki IC, Bellwood DR (1997) Sustained swimming abilities of the late pelagic stages of coral reef fishes. Mar Ecol Prog Ser 149:35-41

Sweatman HPA (1988) Field evidence that settling coral reef fish larvae detect resident fishes using dissolved chemical cues. J Exp Mar Biol Ecol 124:163-174

Thorrold SR (1993) Post-larval and juvenile scombrids captured in light traps: preliminary results from the Central Great Barrier Reef Lagoon. Bull Mar Sci 52:631-641

Thorrold SR, Williams DM (1996) Meso-scale distribution patterns of larval and pelagic juvenile fishes in the central Great Barrier Reef Lagoon. Mar Ecol Prog Ser 145: $17-31$

Thorrold SR, Shenker JM, Maddox ED, Mojica R, Wishinski E (1994a) Larval supply of shorefishes to nursery habitats around Lee Stocking Island, Bahamas. II. Lunar and oceanographic influences. Mar Biol 118:567-578

Thorrold SR, Shenker JM, Mojica RJ, Maddox ED, Wishinski E (1994b) Temporal patterns in the larval supply of summer-recruitment reef fishes to Lee Stocking Island, Bahamas. Mar Ecol Prog Ser 112:75-86

Thorrold SR, Shenker JM, Wishinski E, Mojica R, Maddox ED (1994c) Larval supply of shorefishes to nursery habitats around Lee Stocking Island, Bahamas. I. Small-scale distribution patterns. Mar Biol 118:555-566

Tolimieri N, Jeffs A, Montgomery JC (2000) Ambient sound as a cue for navigation by the pelagic larvae of reef fishes. Mar Ecol Prog Ser 207:219-224

Victor BC (1991) Settlement strategies and biogeography of reef fishes. In: Sale PF (ed) The ecology of fishes on coral reefs. Academic Press, San Diego, CA, p 231-260

Williams C (1988) Larval and juvenile fish assemblages at Ningaloo Reef, Western Australia. 1-53. BSc (Hons) thesis, Murdoch University, Perth

Wilson DT (2001) Patterns of replenishment of coral-reef fishes in the nearshore waters of the San Blas Archipelago, Caribbean Panama. Mar Biol 139:735-753

Submitted: September 11, 2002; Accepted: January 13, 2003 Proofs received from author(s): April 3, 2003 